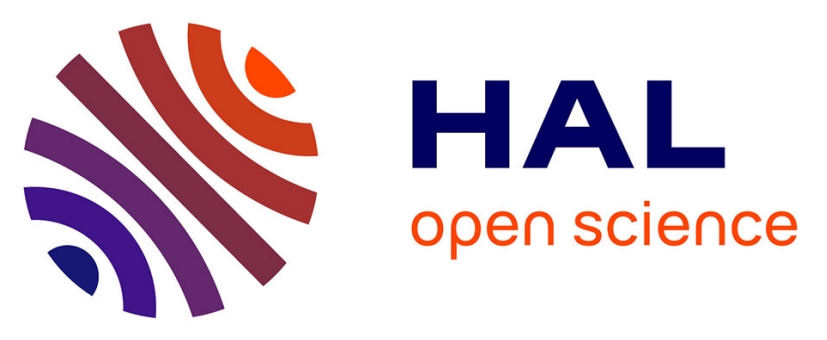

\title{
Development of Novel Oxotriazinoindole Inhibitors of Aldose Reductase: Isosteric Sulfur/Oxygen Replacement in the Thioxotriazinoindole Cemtirestat Markedly Improved Inhibition Selectivity
}

Matúš Hlaváč, Lucia Kováčiková, Marta Šoltésová Prnová, Peter Šramel, Gabriela Addová, Magdaléna Májeková, Gilles Hanquet, Andrej Boháč, Milan Štefek

\section{- To cite this version:}

Matúš Hlaváč, Lucia Kováčiková, Marta Šoltésová Prnová, Peter Šramel, Gabriela Addová, et al.. Development of Novel Oxotriazinoindole Inhibitors of Aldose Reductase: Isosteric Sulfur/Oxygen Replacement in the Thioxotriazinoindole Cemtirestat Markedly Improved Inhibition Selectivity. Journal of Medicinal Chemistry, 2020, 63, pp.369 - 381. 10.1021/acs.jmedchem.9b01747 . hal-03079080

\author{
HAL Id: hal-03079080 \\ https://hal.science/hal-03079080
}

Submitted on 18 May 2021

HAL is a multi-disciplinary open access archive for the deposit and dissemination of scientific research documents, whether they are published or not. The documents may come from teaching and research institutions in France or abroad, or from public or private research centers.
L'archive ouverte pluridisciplinaire $\mathbf{H A L}$, est destinée au dépôt et à la diffusion de documents scientifiques de niveau recherche, publiés ou non, émanant des établissements d'enseignement et de recherche français ou étrangers, des laboratoires publics ou privés. 


\title{
Development of Novel Oxotriazinoindole Inhibitors of Aldose Reductase: Isosteric Sulfur/Oxygen Replacement in the Thioxotriazinoindole Cemtirestat Markedly Improved Inhibition Selectivity
}

\author{
Matúš Hlaváč, ${ }^{\dagger}$ Lucia Kováčiková, ${ }^{\ddagger}$ Marta Šltésová Prnová, ${ }^{\dagger}$ Peter Šramel, ${ }^{\dagger}$ Gabriela Addová, ${ }^{\S}$ \\ Magdaléna Májeková, Gilles Hanquet, $"$ Andrej Boháč ${ }^{\dagger, \perp}$ and Milan Štefek ${ }^{*},+0$ \\ ${ }^{\dagger}$ Department of Organic Chemistry, Faculty of Natural Sciences, Comenius University in Bratislava, Ilkovičova 6, 84215 Bratislava, \\ Slovakia \\ ${ }^{\ddagger}$ Institute of Experimental Pharmacology and Toxicology, CEM, SAS, Dúbravská cesta 9, 84104 Bratislava, Slovakia \\ ${ }^{\S}$ Institute of Chemistry, Faculty of Natural Sciences, Comenius University in Bratislava, Ilkovičova 6, 84215 Bratislava, Slovakia \\ "Université de Strasbourg, Université de Haute-Alsace, CNRS, UMR 7042-LIMA, ECPM, 25 rue Becquerel, 67087 Strasbourg, \\ France \\ ${ }^{\perp}$ Biomagi, Inc., Mamateyova 26, 85104 Bratislava, Slovakia
}

Supporting Information

ABSTRACT: Inhibition of aldose reductase (AR), the first enzyme of the polyol pathway, is a promising approach in treatment of diabetic complications. We proceeded with optimization of the thioxotriazinoindole scaffold of the novel AR inhibitor cemtirestat by replacement of sulfur with oxygen. A series of 2-(3-oxo-2H-[1,2,4] triazino $[5,6-b]$ indol-5(3H)-yl)acetic acid derivatives (OTIs), designed by molecular modeling and docking, were synthesized. More electronegative and less bulky oxygen of OTIs compared to the sulfur of the original thioxotriazinoindole congeners was found to form a stronger $\mathrm{H}$ bond with Leu300 of AR and to render larger rotational flexibility of the carboxymethyl pharmacophore. AR inhibitory activities of the novel compounds were characterized by the $\mathrm{IC}_{50}$ values in a submicromolar range. Markedly enhanced inhibition selectivity relative to the structurally related aldehyde reductase was recorded. To conclude, structure modification of the

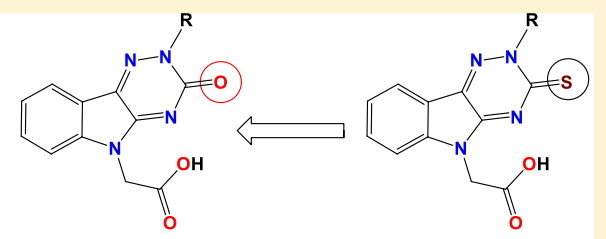

OTIs (oxxotriazinoindoles) \begin{tabular}{ll}
$\mathrm{R}$ & $\mathrm{IC}_{50}$ (selectivity) \\
\hline$-\mathrm{H}$ & $42 \mathrm{nM}(>2380)$
\end{tabular} $-\mathrm{CH}_{2} \mathrm{OCH}_{3} \quad 85 \mathrm{nM}(>1177)$ $-\mathrm{CH}_{2} \mathrm{COOH} \quad 120 \mathrm{nM}(168)$ $-\mathrm{CH}_{2} \mathrm{Ph} \quad 434 \mathrm{nM}(>230)$ $\left(-\mathrm{COCH}_{3},-\mathrm{CO}^{\mathrm{t}} \mathrm{Bu}\right)$ unstable original carboxymethylated thioxotriazinoindole cemtirestat by isosteric replacement of sulfur with oxygen in combination with variable $\mathrm{N}(2)$ simple substituents provided novel analogues with increased AR inhibition efficacy and markedly improved selectivity.

\section{INTRODUCTION}

Despite significant efforts that have been made in the past decade to determine the precise physiological role of aldose reductase (AR, ALR2), our understanding of this enzyme remains limited. AR as the first enzyme of the polyol pathway is considered a major component in the etiology of chronic diabetic complications. Under hyperglycemic conditions, glucose reduction is catalyzed by AR to sorbitol. Sorbitol accumulation in cells and related metabolic derangements result in cataract, damage of peripheral nerves or kidneys and cardiovascular complications. Therefore, efficient AR inhibitors are sought as potential remedies to prevent diabetic complications.

In our previous study, carboxymethylated thioxotriazinoindoles were identified as AR inhibitors with high efficacy and selectivity. ${ }^{1}$ Among the novel compounds, 2-(3-thioxo- $2 \mathrm{H}$ $[1,2,4]$ triazino $[5,6-b]$ indol-5 $(3 H)$-yl)acetic acid (4) (cemtirestat, CMTI, Figures 1 and 3 ) was found the most promising

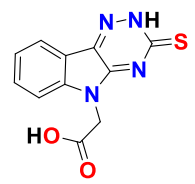

Figure 1. 2-(3-Thioxo- $2 H$ - $[1,2,4]$ triazino $[5,6-b]$ indol-5(3H)-yl)acetic acid (4, cemtirestat, CMTI).

inhibitor endowed also with antioxidant activity. ${ }^{2,3}$ Considering excellent "lead-likeness" of cemtirestat (4), we proceeded with optimization of its thioxotriazinoindole scaffold by replacement of sulfur with oxygen, with the aim to improve the inhibitory efficacy and selectivity. Based on preliminary molecular modeling and docking calculations, a series of 2-(3oxo- $2 H$ - $[1,2,4]$ triazino[ $[5,6-b]$ indol-5(3H)-yl)acetic acid deriv-

Received: October 22, 2019

Published: December 10, 2019 
atives (OTIs) 9-10, 12, and 14 was proposed, synthesized, and their AR inhibitory efficacy and selectivity determined.

\section{RESULTS}

Drug Design. We were inspired by " $\mathrm{S}$ " and "O" series of fused tricyclic AR inhibitors patented by Toyooka et al. (Figure 2). The inhibition efficacy in a low micromolar range was reported for these compounds.

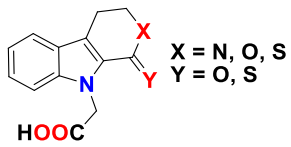

Figure 2. Structure of the published tricyclic AR inhibitors.

In our initial molecular modeling and docking investigation, we were interested how isosteric replacement of $S$ in cemtirestat (4) by $\mathrm{O}$ would affect interaction with AR. In our previous study, three main tautomers of cemtirestat (4) were specified. ${ }^{1}$ Their structures along with the analogical tautomers of an oxygen variant of cemtirestat, compound $\mathbf{9}$, are depicted in Figure 3.

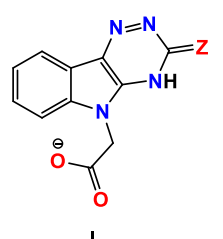

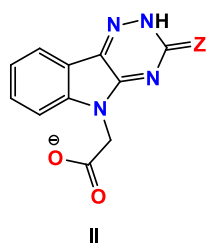

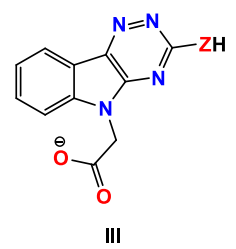

$\mathrm{Z}=\mathrm{S}$ (compound $\mathbf{4})$ or $\mathrm{O}$ (compound $\mathbf{9}$ )

Figure 3. Structures of the most relevant tautomers of cemtirestat (4) and its $\mathrm{O}$-analogue 9.

Energy preferences of the individual tautomers calculated by quantum-mechanical geometry optimization are summarized in Table 1. The order of the relative energies indicates the

Table 1. Relative Energy Preferences of Individual Tautomers of Cemtirestat (4) and Its O-Analogue 9

\begin{tabular}{|c|c|c|c|c|c|c|}
\hline \multirow[b]{3}{*}{ tautomer } & \multicolumn{6}{|c|}{ relative energies $(\mathrm{kJ} / \mathrm{mol})^{a}$} \\
\hline & \multicolumn{3}{|c|}{ cemtirestat (4) } & \multicolumn{3}{|c|}{ compound 9} \\
\hline & vacuum & water & DMSO & vacuum & water & DMSO \\
\hline I & 0.4 & 41.0 & 18.8 & 0 & 47.0 & 23.5 \\
\hline II & 0 & 0 & 0 & 2.5 & 0 & 0 \\
\hline III & 33.8 & 51.9 & 49.0 & 38.9 & 39.4 & 42.5 \\
\hline
\end{tabular}

${ }^{a}$ Values of total energies, calculated as described in the experimental section, related by subtraction to the most stable tautomer in a given environment.

preference of tautomer II for both 4 and 9 in $\mathrm{H}_{2} \mathrm{O}$ or dimethyl sulfoxide (DMSO) solvents. Different polarities, aromaticities, and energy of bonds of individual tautomers are most likely responsible for the observed energy variances calculated in vacuum, water, and DMSO, as shown in Table 1. All three tautomeric forms were docked and optimized in a PDB: 4QX4 model of human recombinant AKR1B1. For compound 9, tautomeric forms I and II provided similar positions, yet the second one was energetically more favorable. Accordingly, molecular dynamics simulations proved that tautomer II of cemtirestat (4) gave a more stable complex with AKR1B1. ${ }^{5}$

Figure 4 shows superposition of cemtirestat (4) and its $\mathrm{O}$ analogue 9 in the binding site of AKR1B1. Polar

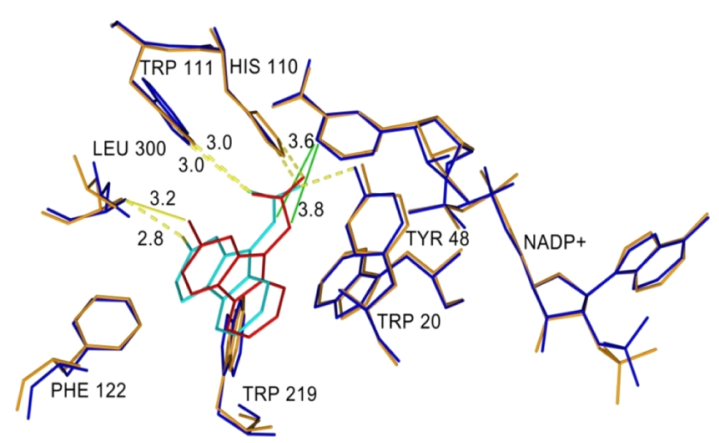

Figure 4. Superposition of 9 and cemtirestat (4) in the binding site of AKR1B1 (PDB: 4QX4). Cemtirestat (4) is colored in red and the corresponding amino acid residues in orange. Compound 9 is shown in cyan and the complementary amino acid residues in dark blue. $\mathrm{H}$ bonds are indicated as yellow and hydrophobic interactions as green lines.

carboxymethyl groups of both compounds were found to align well. Slight distortion of the fused planar aromatic system was apparently caused by higher rotational flexibility of the carboxymethyl moiety of 9 (in cyan) owing to less bulky oxygen compared to the sulfur of the original thioxotriazinoindole 4 (in red, the van der Waals radius of $\mathrm{O}$ is $1.4 \AA$, while for $S$ it is $1.9 \AA$ ). As a result, compound 9 was able to create a stronger H-bond with Leu300 (contact distance $2.8 \AA$ vs $3.2 \AA$ ) and gave more favorable hydrophobic interaction $\left(2.0 \mathrm{~kJ} / \mathrm{mol}\right.$ for $9 \mathrm{vs} 0.6 \mathrm{~kJ} / \mathrm{mol}$ for cemtirestat 4) with $\mathrm{NADP}^{+}$ (contact distance $3.6 \AA$ vs $3.8 \AA$ ). Compound 9 interacts with the residues of the specificity pocket Phe122 and Leu300 while letting the specificity pocket be closed (Figures 4 and 5), which
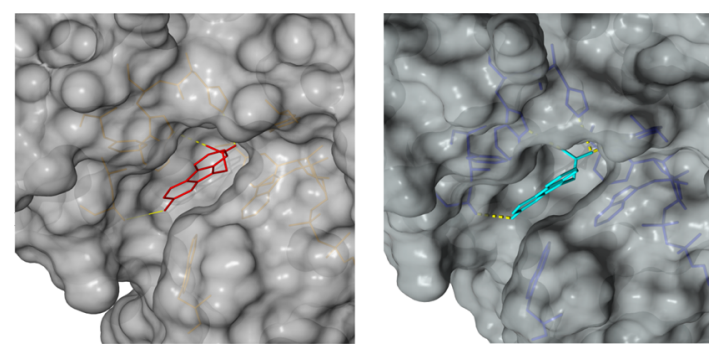

Figure 5. Positions of cemtirestat 4 (left, PDB: 4QX4) and compound 9 (right, predicted) in the cavities of the AKR1B1 binding site. The yellow lines closer to an active site entrance label contact distances with Leu300 of the specificity pocket.

is in line with the previously published crystal structure of AKR1B1 complexed with cemtirestat 4 (PDB: 4QX4). ${ }^{1}$ These preliminary in silico findings provided a promise of better fitting of the O-derivative 9 into the binding site of $\mathrm{AR}$ when compared with its parent molecule of cemtirestat (4).

Chemistry. A commercially available compound, 2-(3thioxo- $2 H$ - $[1,2,4]$ triazino $[5,6-b]$ indol-5 $(3 H)$-yl)acetic acid (4) [CAS: 309283-89-4], recently identified as an ALR2 inhibitor ${ }^{1}$ and reported also under the designation of cemtirestat, ${ }^{3,6}$ is to our knowledge devoid of any literature report on its chemical synthesis. ${ }^{7}$ Therefore, we developed a procedure for its 
Scheme 1. Preparation of Cemtirestat (4) from Isatine (1)

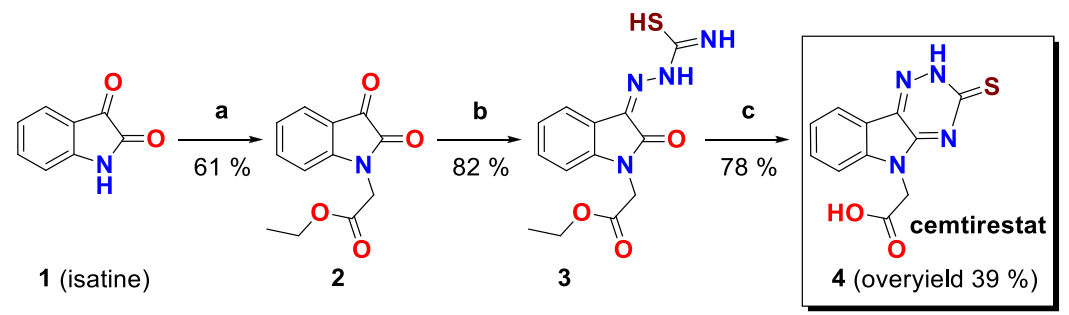

${ }^{a}$ Reagents and conditions: (a) (1) $\mathrm{CaH}_{2} 1.10 \mathrm{~mol}$ equiv, DMF (abs), $100{ }^{\circ} \mathrm{C}, 1 \mathrm{~h}$; (2) ethyl chloroacetate $3.00 \mathrm{~mol}$ equiv, $40-100{ }^{\circ} \mathrm{C}, 5 \mathrm{~h} .(\mathrm{b})$ Thiosemicarbazide 1.20 mol equiv, DMF (abs), $100{ }^{\circ} \mathrm{C}, 1 \mathrm{~h}$. (c) $\mathrm{K}_{2} \mathrm{CO}_{3} 15 \%$ aq sol, reflux, $48 \mathrm{~h}$.

\section{Scheme 2. Synthesis of Predicted Inhibitors 9 and 10 from Isatine $1^{a}$}

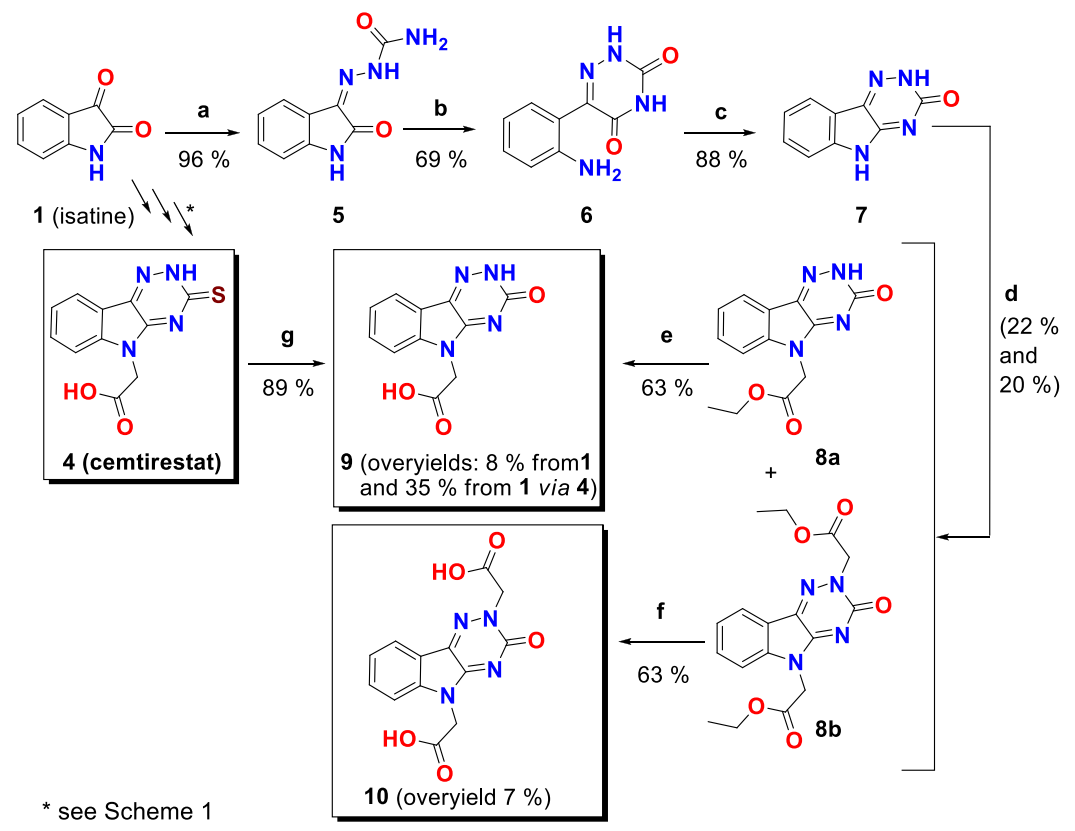

${ }^{a}$ Reagents and conditions: (a) semicarbazide hydrochloride 1.20 mol equiv, EtOH, reflux, $30 \mathrm{~min}$. (b) $\mathrm{NaOH}$ (aq $1.00 \mathrm{M}$ ), reflux, overnight. (c) Glacial acetic acid, reflux, $3 \mathrm{~h}$. (d) (1) $\mathrm{CaH}_{2} 2.00 \mathrm{~mol}$ equiv, DMF (abs), $60^{\circ} \mathrm{C}, 40 \mathrm{~min}$; (2) ethyl chloroacetate $2.50 \mathrm{~mol}$ equiv, $50{ }^{\circ} \mathrm{C}, 3 \mathrm{~h}$, separated by FLC on $\mathrm{SiO}_{2}$. (e) $\mathrm{NaOH} 2.00$ mol equiv, $\mathrm{MeOH} / \mathrm{H}_{2} \mathrm{O}: 4 / 1$, reflux, 2 h. (f) $\mathrm{NaOH} 3.50$ mol equiv, $\mathrm{MeOH} / \mathrm{H}_{2} \mathrm{O}: 4 / 1, \mathrm{reflux}, 1.5$ h. (g) (1) $\mathrm{NaOH} 2.00$ mol equiv, $\mathrm{H}_{2} \mathrm{O}$; (2) $\mathrm{KMnO}_{4} 2.00$ mol equiv, $\mathrm{NaOH}, 5.50$ mol equiv, $\mathrm{H}_{2} \mathrm{O}$, rt, 30 min.

\section{Scheme 3. Synthesis of 12 and 14 from the Joint Intermediate $8 a^{a}$}

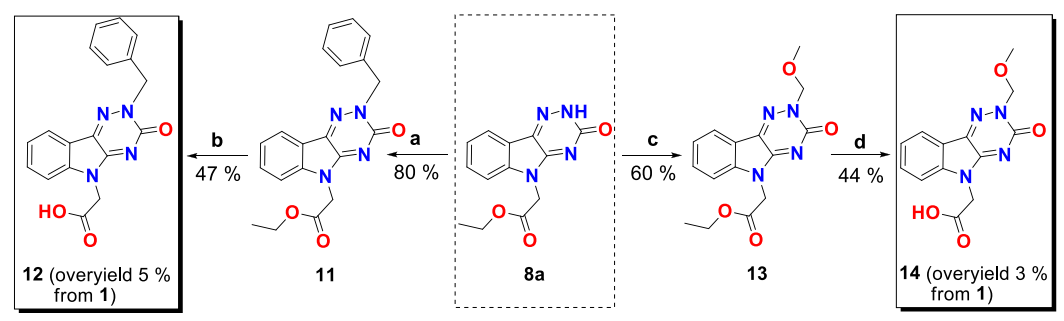

${ }^{a}$ Reagents and conditions: (a) (1) $\mathrm{CaH}_{2} 2.00 \mathrm{~mol}$ equiv, DMF (abs), $50{ }^{\circ} \mathrm{C}, 30 \mathrm{~min}$; (2) benzyl chloride $4.00 \mathrm{~mol}$ equiv, $80{ }^{\circ} \mathrm{C}, 4 \mathrm{~h} .(\mathrm{b}) \mathrm{NaOH}$ $2.00 \mathrm{~mol}$ equiv, $\mathrm{MeOH} / \mathrm{H}_{2} \mathrm{O}: 3 / 1$, reflux, $2 \mathrm{~h}$. (c) Methoxymethylchloride 5.00 mol equiv, Hünig's base (N,N-diisopropylethylamine, DIPEA) $5.00 \mathrm{~mol}$ equiv, acetone (abs) from rt to $50{ }^{\circ} \mathrm{C}, 5 \mathrm{~h}$. (d) $\mathrm{NaOH} 2.00 \mathrm{~mol}$ equiv, $\mathrm{MeOH} / \mathrm{H}_{2} \mathrm{O}: 3 / 1,80{ }^{\circ} \mathrm{C}, 1 \mathrm{~h}$

preparation from isatine (1). Compound $\mathbf{1}$ was alkylated to $\mathbf{2}$ by deprotonation using calcium hydride, ${ }^{8}$ followed by addition of an excess of ethyl chloroacetate in $N, N$-dimethylformamide (DMF) and stirring at $100{ }^{\circ} \mathrm{C}$ within $5 \mathrm{~h}$. The resulting compound 2 underwent condensation with thiosemicarbazide in DMF at $100{ }^{\circ} \mathrm{C}$ to give intermediate 3. Finally, the latter was refluxed in an aqueous solution of potassium carbonate during two days to afford the ALR2 inhibitor 4 in overall yield $39 \%$ (Scheme 1).

The synthetic route to the other computer-predicted compounds $\mathbf{9}$ and $\mathbf{1 0}$ is summarized in Scheme 2. Exploitation of the synthetic pathway applied for the sulfur-containing compound cemtirestat (4) was unproductive in preparation of its oxo-analogue 9 because the 2-carbamoylhydrazonocontaining intermediate (a tautomeric oxo-isoster of 3 from 
Scheme 4. Synthesis of 15 and 17 from the Intermediate 8a and One of the Target Compounds $9^{a}$

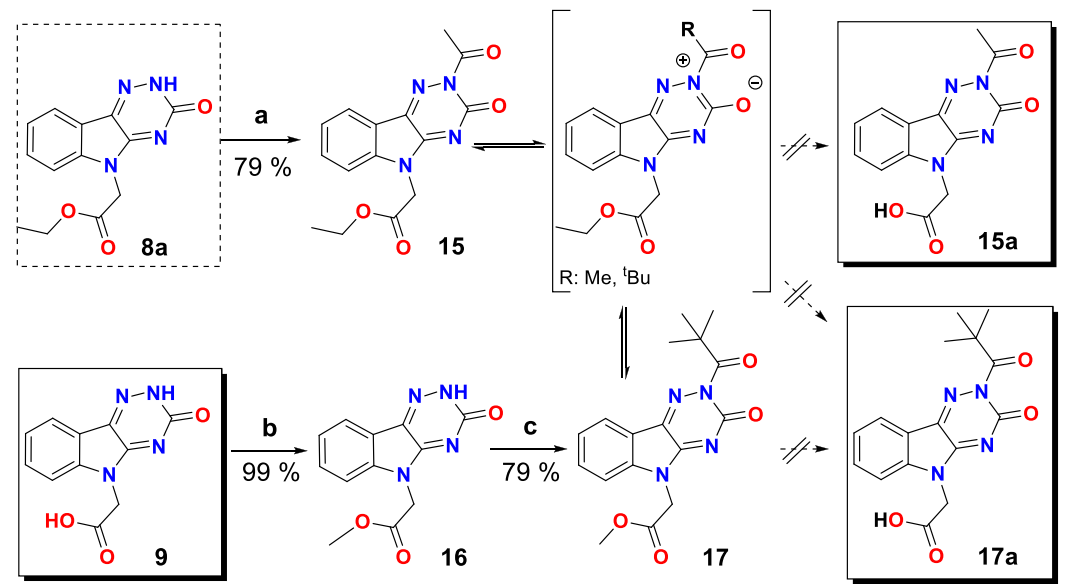

${ }^{a}$ Reagents and conditions: (a) Acetyl chloride 2.00 mol equiv, $N, N$-dimethylaminopyridine (DMAP) 1.00 mol equiv, Hünig base ( $N, N$ diisopropylethylamine, DIPEA) $1.60 \mathrm{~mol}$ equiv, $\mathrm{CH}_{2} \mathrm{Cl}_{2}$, rt to $40{ }^{\circ} \mathrm{C}, 1 \mathrm{~h}$. (b) Solution of diazomethane in $\mathrm{Et}_{2} \mathrm{O}$. (c) Pivaloyl chloride 2.00 mol equiv, DMAP $1.00 \mathrm{~mol}$ equiv, Hünig's base $1.50 \mathrm{~mol}$ equiv, $\mathrm{CH}_{2} \mathrm{Cl}_{2}$, rt to $30^{\circ} \mathrm{C}, 15 \mathrm{~min}$.

Table 2. Enzyme Inhibition Data

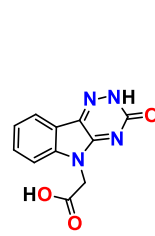

9

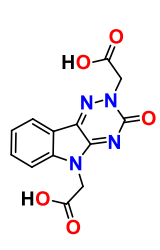

10

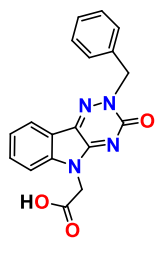

12

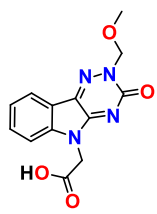

14

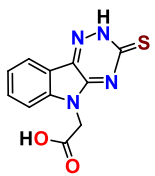

cemtirestat (4)

\begin{tabular}{|c|c|c|c|c|}
\hline \multirow[b]{2}{*}{ compound } & \multicolumn{2}{|c|}{ ALR2 $\mathrm{IC}_{50}(\mathrm{nM})$} & $\mathrm{ALR}_{1} \mathrm{IC}_{50}(\mu \mathrm{M}) / I(\%, 100 \mu \mathrm{M})$ & \multirow[b]{2}{*}{$\mathrm{SF}_{\mathrm{H}_{2} \mathrm{O}}=\mathrm{IC}_{50}(\mathrm{ALR} 1) / \mathrm{IC}_{50}(\mathrm{ALR} 2)$} \\
\hline & $1 \%$ DMSO & $\mathrm{H}_{2} \mathrm{O}$ & $\mathrm{H}_{2} \mathrm{O}$ & \\
\hline 9 & $51 \pm 1$ & $42 \pm 1$ & $>100 / 24.0$ & $>2380$ \\
\hline 10 & $233 \pm 13$ & $120 \pm 5$ & $20.2 \pm 0.4 /$ n.d. & 168 \\
\hline 12 & $787 \pm 8$ & $434 \pm 14$ & $>100 / 37.8$ & $>230$ \\
\hline 14 & $118 \pm 3$ & $85 \pm 1$ & $>100 / 13.4$ & $>1177$ \\
\hline cemtirestat (4) & $176 \pm 13$ & $116 \pm 8$ & $35.0 \pm 1.6 /$ n.d. & 302 \\
\hline cemtirestat $^{a}$ & n.d. & $97 \pm 19$ & $40.6 \pm 2.0 /$ n.d. & 418 \\
\hline epalrestat $^{b}$ & $227 \pm 19$ & n.d. & n.d. & \\
\hline valproic $\operatorname{acid}^{a}$ & n.d. & n.d. & $56.1 \pm 2.7$ & \\
\hline
\end{tabular}

${ }^{a}$ Stefek et al. (2015). ${ }^{1}$ Majekova et al. (2017), ${ }^{17}$ n.d.-not determined. $\mathrm{SF}_{\mathrm{H}_{2} \mathrm{O}}$ means the selectivity factor calculated from IC $\mathrm{C}_{50}$ data measured in water. Results are mean values from two measurements or mean values \pm SD from at least three measurements. $I$ is the \% of enzyme inhibition observed at $100 \mu \mathrm{M}$ inhibitor concentration. All measurements were performed by using the same enzyme batch of either ALR1 or ALR2.

Scheme 1; its structure is not given) did not cyclize under basic conditions. Therefore, in this case isatine (1) was refluxed with semicarbazide hydrochloride in ethanol ${ }^{9}$ to give compound $\mathbf{5}$ in $96 \%$ yield $^{10-12}$ which upon reflux with an aqueous solution of sodium hydroxide $(1.0 \mathrm{M})$ overnight lead to triazinedione 6 in $69 \%$ yield $^{13}$ (Scheme 2).

Acidic treatment of 6 followed by alkylation ${ }^{14}$ of the resulting triazino-indole derivative 7 with ethyl chloroacetate afforded a 1:1 mixture of mono and dialkylated products 8a and $\mathbf{8 b}$ in relatively low yields of 22 and $20 \%$, respectively, after FLC separation on $\mathrm{SiO}_{2}$. Finally, hydrolysis of $\mathbf{8 a}$ and $\mathbf{8 b}$ under basic conditions delivered 9 and $\mathbf{1 0}$ in 63\% yield for both. However, the overall yield of the target compound 9 was largely improved (35\% vs $8 \%$ ) by direct oxidative-hydrolysis of 4 by potassium permanganate in an aqueous solution of sodium hydroxide. ${ }^{9}$ Compound 8a represents an important joint intermediate for the synthesis of other predicted inhibitors 12 and 14 which both were prepared from 1 (over six steps) in 5 and 3\% yields according to the Schemes 2 and 3. Compound 8a was alkylated to corresponding $N$-benzyl- and $N$-MOM-derivatives 11 and 13, respectively, which were subsequently saponified under basic conditions to compounds 12 and 14.

Finally, compounds 15 and 17 were prepared from their precursors 8a and 9, respectively. Esters 15 and 17 were thought to be precursors of acyl-carboxylic acids 15a and 17a as predicted inhibitors providing an additional hydrogen bond in interaction with the ALR2 enzyme. Compound 15 was obtained in $79 \%$ yield by acetylation of $8 \mathbf{a}$. The acyl-triazinone 17 was prepared from 9 that underwent almost quantitative esterification to $\mathbf{1 6}$ followed by acylation with pivaloyl chloride to $\mathbf{1 7}$ in $79 \%$ yield. Unfortunately, both compounds $\mathbf{1 5}$ and $\mathbf{1 7}$ were quite unstable because of their labile acyl group bounded on the annulated and partially aromatic 1,2,4-triazine-3-one ring (its general mesomeric aromatic structure is depicted in Scheme 4 in parenthesis). Thus, hydrolysis of $\mathbf{1 5}$ and $\mathbf{1 7}$ to $\mathbf{1 5 a}$ 
and 17a was impossible and we have not been able to screen both the predicted inhibitors on ALR2.

Detailed characterizations and spectra of all the products mentioned (Schemes 1-4) are described in the Supporting Information to this paper.

Enzyme Inhibition. The compounds 9, 10, 12, and 14 were assessed for their ability to inhibit the in vitro reduction of $D, L$-glyceraldehyde by ALR2 purified from rat lens, using cemtirestat (4) as a reference (Table 2). Higher $\mathrm{IC}_{50}$ values (1.2-1.9 times) were recorded in the presence of $1 \%$ DMSO in the solvent.

In the next step, we evaluated the inhibition selectivity in relation to the closely related antitarget aldehyde reductase (ALR1). The inhibition data of OTI compounds 9, 10, 12, and 14 for their inhibition of the reduction of the D-glucuronate substrate by ALR1 purified from rat kidneys are shown in Table 2 together with the selectivity factors calculated [SF = $\mathrm{IC}_{50}(\mathrm{ALR} 1) / \mathrm{IC}_{50}$ (ALR2)].

For comparison, inhibition data of epalrestat, well-known inhibitor of ALR2, ${ }^{15}$ and valproic acid, inhibitor of ALR1, ${ }^{16}$ obtained under the identical experimental conditions as those for the compounds studied, are also included in Table 2.

Moreover, inhibition of human recombinant AKR1B1 was assayed. The data shown in Table 3 were obtained under identical reaction conditions as applied for the rat ALR2 assay, with a protein concentration of $5 \mu \mathrm{g} / \mathrm{mL}$.

Table 3. Inhibition of Human Recombinant Enzymes by 9 in Comparison with Cemtirestat (4)

\begin{tabular}{ccc} 
& \multicolumn{2}{c}{$\mathrm{IC}_{50}(\mathrm{nM})$} \\
\cline { 2 - 3 } human recombinant enzyme & 9 & cemtirestat (4) \\
AKR1B1 & $66 \pm 2$ & $102 \pm 5$ \\
AKR1B10 & $56240 \pm 5758$ & $21400 \pm 2000^{a}$
\end{tabular}

${ }^{a}$ Stefek et al. (2015). ${ }^{1}$ The experiments were performed in the absence of DMSO. Results are mean values \pm SD from at least three measurements.

Inhibition of human recombinant AKR1B10 by 9 was tested with $5 \mathrm{mM}$ DL-glyceraldehyde as a substrate, $0.12 \mathrm{mM}$ nicotinamide adenine dinucleotide phosphate cofactor and $10 \mu \mathrm{g} / \mathrm{mL}$ protein concentration, yielding an $\mathrm{IC}_{50}$ value as shown in Table 3.

In addition, inhibition of ALR2-mediated reduction of physiologically relevant substrates, methylglyoxal, 4-hydroxynonenal (HNE), and 4-hydroxynonenal glutathione (GSHNE), by 9 and 4 was determined. In the first step, Michaelis-Menten constants $K_{\mathrm{m}}$ were determined for each substrate. Then the substrate concentrations were set to be minimally 10 times higher than the corresponding $K_{\mathrm{m}}$, to saturate the active site of the enzyme, and $\mathrm{IC}_{50}$ values were determined for both 9 and cemtirestat (4) as shown in Table 4.

No significant inhibition of sorbitol dehydrogenase activity (the second enzyme of the polyol pathway) by $100 \mu \mathrm{M}$ concentration of 9 was recorded $[I(\%)=0.9 \pm 0.6, n=3]$.

The inhibitory effect of 9 on sorbitol accumulation in isolated rat eye lenses was evaluated. As shown in Figure 6, significantly increased sorbitol levels were shown in the isolated rat eye lenses incubated with glucose, $\mathrm{C}(+)$, in comparison with control incubations without glucose, $\mathrm{C}(-)$. Sorbitol accumulation was significantly and in a concentration-
Table 4. Inhibition of ALR2-Mediated Reduction of Three Physiologically Relevant Substrates by 9 and Cemtirestat (4) in Comparison with the D,L-Glyceraldehyde Substrate ${ }^{a}$

\begin{tabular}{lccc} 
& & \multicolumn{2}{c}{$\mathrm{IC}_{50}(\mathrm{nM})$} \\
\cline { 3 - 4 } \multicolumn{1}{c}{ substrate $(\mathrm{mM})$} & $K_{\mathrm{m}}(\mu \mathrm{M})$ & 9 & cemtirestat (4) \\
D,L-glyceraldehyde $(5.0)$ & $239 \pm 66$ & $42 \pm 2$ & $116 \pm 8$ \\
methylglyoxal (0.5) & $38.5 \pm 3.3$ & $40 \pm 1$ & $146 \pm 29$ \\
HNE (0.5) & $32.0 \pm 3.9$ & $216 \pm 14$ & $644 \pm 16$ \\
GS-HNE (1.0) & $84.7 \pm 2.5$ & $292 \pm 25$ & $1157 \pm 78$
\end{tabular}

${ }^{a}$ Results are mean values \pm SD from at least three measurements.

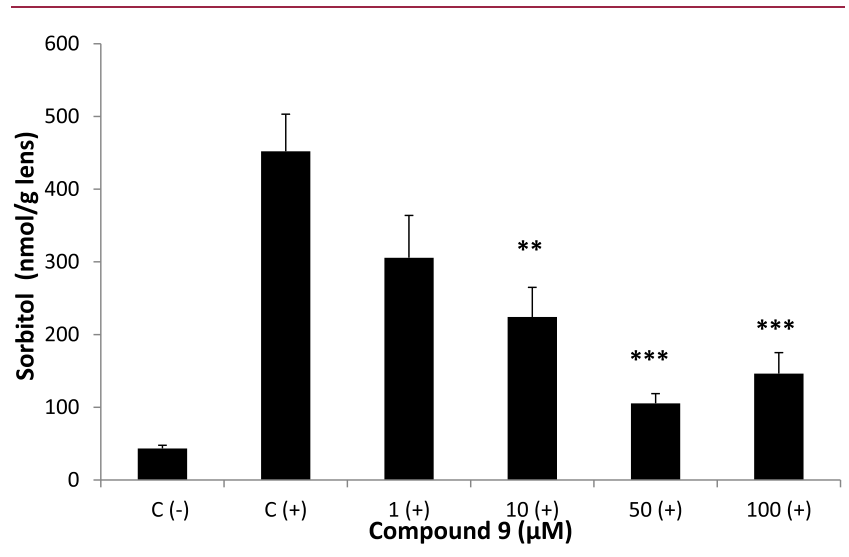

Figure 6. Effect of compound 9 on accumulation of sorbitol in isolated rat eye lenses incubated in the presence of high concentrations of glucose. $\mathrm{C}(-)$, control incubation without glucose; $\mathrm{C}(+)$, control incubation with $50 \mathrm{mM}$ of glucose; and $1(+), 10(+)$, $50(+)$, and $100(+)$ incubations with increasing $\mu \mathrm{M}$ concentrations of compound 9 in the presence of $50 \mathrm{mM}$ glucose. Results are mean values \pm SEM from at least five independent incubations. $* * p \leq 0.01$ vs $\mathrm{C}(+), * * * p \leq 0.001$ vs $\mathrm{C}(+)$; one-way ANOVA followed by the post-hoc Tukey multiple comparison test.

dependent way inhibited by compound 9, starting at a concentration as low as $10 \mu \mathrm{M}$ (Figure 6).

Antioxidant Activity. The 2,2-diphenyl-1-picrylhydrazyl (DPPH) test was employed to evaluate the radical scavenging efficacy of compound 9 in comparison with that of cemtirestat (4). The time course of the specific absorbance decrease of the ethanolic solution of DPPH (a free radical of 2,2-diphenyl-1(2,4,6-trinitrophenyl)hydrazyl, CAS [1898-66-4]) at $518 \mathrm{~nm}$ in the presence of $\mathbf{9}, \mathbf{1 4}, \mathbf{4}$, and standard melatonin is plotted in Figure 7. Considerably decreased scavenging activity of 9 was recorded in comparison with that of cemtirestat (4). Yet the initial velocity of DPPH radical quenching by 9 was still higher than that of standard melatonin, Table 5.

Physicochemical Properties and Molecular Obesity. Molecular obesity indices, generally used to assess oral bioavailability or "drug-likeness", ${ }^{19-22}$ were calculated for the novel compounds $9,10,12,14$, and for cemtirestat (4), taking into account efficacy, size, and lipophilicity, as shown in Table 6.

\section{DISCUSSION}

Aldose reductase (AR, ALR2, and AKR1B1), the first enzyme of the polyol pathway, has been implicated in the pathophysiology of diabetes-related complications. ${ }^{23}$ This enzyme has also been shown to reduce the carbonyl functional group of lipid peroxidation products, thus supporting the inflammation as a consequence. ${ }^{24} \mathrm{AR}$ inhibitors (ARIs) thus 


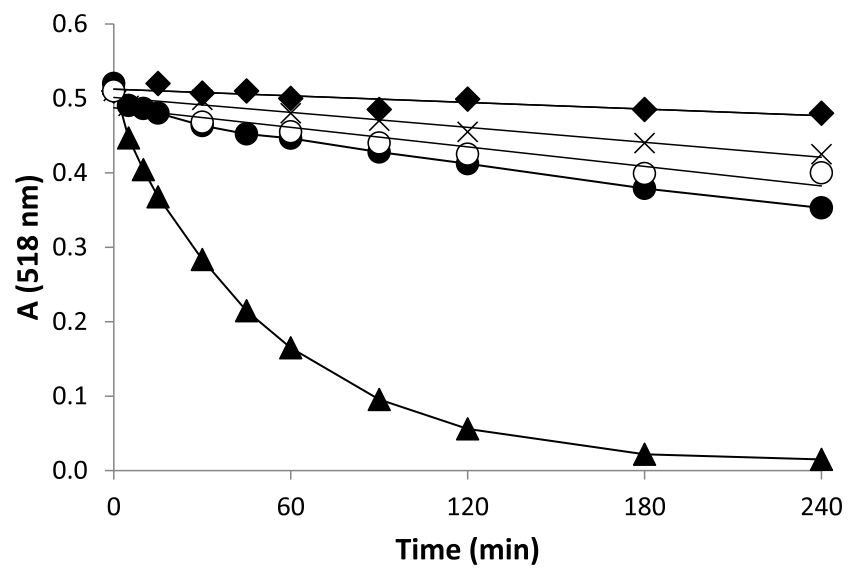

Figure 7. Time course of the absorbance drop of ethanolic solution of DPPH radical $(50 \mu \mathrm{M})$ in the presence of $200 \mu \mathrm{M}$ concentration of the compounds evaluated at $\lambda_{\max }=518 \mathrm{~nm}$. ( $)$ Blank, $(\times)$ melatonin, (O) compound 14, (O) compound 9, and (A) cemtirestat (4). Typical curves from measurements performed under identical conditions.

\section{Table 5. DPPH Test}

$\begin{array}{lcc}\quad \text { compound } & C(\mu \mathrm{M}) & -\Delta A / 30 \min \pm \mathrm{SD} \\ \text { Blank } & & 0.013 \pm 0.012 \\ \mathbf{9} & 200 & 0.057 \pm 0.008 \\ \mathbf{1 4} & 200 & 0.042 \pm 0.006 \\ \left.\text { cemtirestat }^{(4)}\right)^{18} & 200 & 0.219 \pm 0.005 \\ \text { melatonin }^{18} & 200 & 0.022 \pm 0.006\end{array}$

The stable free radical of DPPH $(50 \mu \mathrm{M})$ dissolved in ethanol was incubated in the absence (blank) or presence of $9,14,4$, or melatonin $(200 \mu \mathrm{M})$. Absorbance decline at $518 \mathrm{~nm}$ was assessed after the initial 30 -min interval. Results are mean values \pm SD from at least three measurements.

present a promising therapeutic approach to treat variety of diabetic complications and inflammatory disorders including some types of cancers related to chronic inflammation. ${ }^{23,25}$ ARIs, such as acetic acid derivatives (epalrestat, zopolrestat), spiro hydantoins (sorbinil), or spiro succinimides (minalrestat), have been mainly studied in relation to diabetic complications yet with poor clinical outcome. ${ }^{26-28}$ At the present time, epalrestat is the sole ARI approved for clinical use but only in the Asian market. ${ }^{29}$ In the pursuit for more efficient ARIs of high selectivity and good bioavailability, the interest has been oriented in recent years toward new chemotypes. $^{30-32}$
A recently developed ARI, 2-(3-thioxo- $2 \mathrm{H}$-[1,2,4]triazino[5,6-b]indol-5-yl)acetic acid (cemtirestat, 4), belongs to a group of novel carboxymethylated thioxotriazinoindole ARIs of high inhibitory efficacy characterized with an $\mathrm{IC}_{50}$ in a submicromolar scale and high selectivity in relation to congeneric aldo-keto reductases. ${ }^{1-3}$ High resolution X-ray crystallography of the human recombinant AKR1B1 enzyme complexed with cemtirestat (4) demonstrated a unique pattern of cemtirestat binding, with the specifity pocket closed, contrary to the interaction of the structurally related lidorestat. ${ }^{1}$ As shown in our latest in vivo study, cemtirestat (4) normalized symptoms of diabetic peripheral neuropathy in Zucker diabetic fatty rats with high significance. ${ }^{6}$ Moreover, "lead-like" structural features of cemtirestat (4) render the compound a favorable candidate for structure optimization.

The rationale for bioisosteric replacement of sulfur with oxygen arose from preliminary molecular modeling and docking study which pointed to preferable fitting of the $\mathrm{O}$ derivative into the inhibitor binding site of AR. Indeed, the Ovariant of cemtirestat, oxotriazinoindole (OTI) compound 9, demonstrates significantly increased inhibition efficacy characterized by $\mathrm{IC}_{50}$ values 2-3 times lower compared to 4, depending on the solvent used. Structure activity relationship (SAR) evaluation in the series of novel OTI derivatives revealed that the presence of simple substituents at $\mathrm{N}(2)$ position of 9 decreased their ALR2 inhibition efficacy. The most remarkable decrease was recorded for compound 12 with the lipophilic benzyl substituent. Higher $\mathrm{IC}_{50}$ values were recorded for measurements performed in the presence of DMSO (1\%) compared to assays in water only. DMSO, which is often used to keep hydrophobic compounds in solution, was recently reported to act as a weak AR differential inhibitor. ${ }^{33}$

All compounds evaluated were revealed to be less efficient inhibitors of ALR1 compared to ALR2. With exception of compound 10, the ALR1 IC 50 values of the OTI derivatives (9, 12, and 14) were found to be over $100 \mu \mathrm{M}$. For these derivatives, the percentage inhibition $I$ (\%) at $100 \mu \mathrm{M}$ concentration of the inhibitor was determined. Estimates of the particular selectivity factors calculated for the most efficient inhibitors 9 and 14 were found to be $>2380$ and $>1177$, respectively, striking an enormous increase of the selectivity factor in the couple cemtirestat (4) versus 9 (from 302 to >2380, Table 2). Calculations of molecular docking into the binding site of ALR1 may offer a feasible explanation: cation $-\pi$ interaction of protonated Arg312 in ALR1 with the aromatic ring of O-derivative 9 supported by two $\mathrm{H}$-bonds keeps this molecule out of reach of the $\mathrm{NADP}^{+}$cofactor in

Table 6. Physicochemical Properties and Molecular Obesity Indices Calculated for Compounds 9, 10, 12, and 14 in Comparison with Cemtirestat (4)

\begin{tabular}{|c|c|c|c|c|c|c|c|c|c|c|c|}
\hline compound & $\begin{array}{c}\text { MW } \\
<500^{h}\end{array}$ & $\mathrm{p} K_{\mathrm{a}}$ & $\mathrm{pK}_{\mathrm{a}}^{a}$ & $\begin{array}{l}\mathrm{pIC}_{50} \\
\text { ALR2 }\end{array}$ & $\begin{array}{l}\log P^{b} \\
<5^{h}\end{array}$ & $\log D^{a}$ & $\begin{array}{c}\mathrm{LE}^{c} \\
>0.3^{h}\end{array}$ & $\begin{array}{c}\mathrm{BEI}^{d} \\
>14.7^{h}\end{array}$ & $\begin{array}{l}\operatorname{LLE}^{e} \\
>3.8^{i}\end{array}$ & $\begin{array}{l}\operatorname{LELP}^{f} \\
<7.5^{h}\end{array}$ & $\begin{array}{c}\text { TPSA }^{g} \\
60-140^{h}\end{array}$ \\
\hline 9 & 244.21 & 3.71 & 4.14 & 7.38 & 1.08 & -1.75 & 0.57 & 30.23 & 5.67 & 2.98 & 100.87 \\
\hline 10 & 302.24 & 3.59 & 4.14 & 6.92 & 0.87 & -6.06 & 0.44 & 22.92 & 6.05 & 1.98 & 127.31 \\
\hline 12 & 334.33 & 3.74 & 4.14 & 6.36 & 3.11 & -0.26 & 0.36 & 19.05 & 3.25 & 8.73 & 90.01 \\
\hline 14 & 288.26 & 3.64 & 4.14 & 7.07 & 1.53 & -1.89 & 0.47 & 24.55 & 5.54 & 3.25 & 99.2 \\
\hline cemtirestat (4) & 260.27 & 3.99 & 4.30 & 6.94 & 1.82 & -1.58 & 0.54 & 26.68 & 5.12 & 3.37 & 83.8 \\
\hline
\end{tabular}

${ }^{a}$ Calculated with Pallas 3.112, $\log D$ represents the logarithm of the distribution ratio in octanol-buffer [pH 7]. ${ }^{b}$ Calculated with MarvinSketch Online 2016/ChemAxon. ${ }^{c}$ Ligand efficiency, $\mathrm{LE}=-1.4 \log \left(\mathrm{IC}_{50}\right) / \mathrm{N}, \mathrm{N}$ : number of heavy atoms. ${ }^{d}$ Binding efficiency index, $\mathrm{BEI}=\mathrm{pIC} \mathrm{C}_{50} / \mathrm{MW}$. ${ }^{e}$ Lipophilic ligand efficiency, LLE $=\mathrm{pIC}_{50}-\log P_{.}{ }^{f}$ Ligand efficiency-dependent lipophilicity, LELP $=\log P /$ LE. ${ }^{g}$ Topological polar surface area $\left(\AA^{2}\right)$, TPSA calculated with MedChem Designer. ${ }^{h}$ Optimal drug values. ${ }^{19-22}{ }^{i}$ Mean value for successful lead. ${ }^{21}$ 
contrast to more tightly attached cemtirestat 4 (Figure S52 in Supporting Information). In addition, a hydrophobic interaction between the methylene residue of an acetate group of 9 and 4, respectively, and the nicotinamide ring of $\mathrm{NADP}^{+}$ should also be taken into consideration. ${ }^{34}$

Based on the $\mathrm{IC}_{50}$ values shown in Table 2, compound 9 inhibits ALR2 more efficiently $\left(\mathrm{IC}_{50}=51 \mathrm{nM}\right)$ than the reference inhibitor epalrestat $\left(\mathrm{IC}_{50}=227 \mathrm{nM}\right)$ while ALR1 activity was inhibited by 9 less efficiently $\left(\mathrm{IC}_{50}>100 \mathrm{nM}\right)$ in comparison with the standard inhibitor of ALR1 valproic acid $\left(\mathrm{IC}_{50}=56 \mathrm{nM}\right)$.

In assaying inhibition of human recombinant AKR1B1, values closely related to those of the rat ALR2 enzyme were obtained for 9 and cemtirestat (4) (Table 3 vs Table 2). Markedly less efficient inhibition of AKR1B10 by 9 compared to AKR1B1 was characterized (Table 3 ) by a selectivity factor above 850 .

Enzyme-inhibitor interactions of selected ARIs were surveyed. Interaction diagrams and visualized binding sites of AKR1B1 complexed with cemtirestat (4), tolrestat, zopolrestat, epalrestat, and fidarestat in comparison with those of compound 9 are shown in the Supporting Information. Experimental values of $\mathrm{IC}_{50}$ for inhibition of AKR1B1, numbers of hydrogen bonds with amino acid residues of the binding site $\left(\mathrm{HB}_{\mathrm{AA}}\right)$, numbers of hydrogen bonds with water molecules $\left(\mathrm{HB}_{\mathrm{w}}\right)$, numbers of $\pi-\pi$ interactions, values of the smallest distance of the hydrophobic interaction between the methylene group of the acetate substituent and the nicotine amide ring of $\mathrm{NADP}^{+}\left(\mathrm{d}_{\mathrm{hph}}\right.$, if exists $)$ and the distance of anion $-\pi$ interaction $\left(d_{\text {anion }-\pi}\right)$ between the carboxylic oxygen (or hydantoin oxygen in fidarestat), and the positively charged nicotinamide ring of $\mathrm{NADP}^{+}$are summarized in Table $\mathrm{S} 1$ in Supporting Information.

AR is a low selectivity oxidoreductase which can utilize both hydrophilic and hydrophobic aldehydes as substrates. However, this enzyme appears to be not wholly admissible because it may discriminate between variable substrates. The ability of diverse substrates to interact with AR with variable affinity suggests that these molecules may approach the active site of the enzyme in multiple ways. ${ }^{35}$ Indeed diverse $K_{\mathrm{m}}$ values were obtained for three alternative substrates studied, methylglyoxal (38.5 $\mu \mathrm{M}), \mathrm{HNE}(32.0 \mu \mathrm{M})$, and GS-HNE $(84.7 \mu \mathrm{M})$, in comparison with D,L-glyceraldehyde $(239 \mu \mathrm{M})$ as shown in Table 4. Inhibition efficacies of 9 and cemtirestat (4) were determined with the AR active site saturated with the substrates. Under these conditions, both 9 and cemtirestat (4) only poorly discriminated in their inhibition efficacy between methylglyoxal and D,L-glyceraldehyde substrates in spite of their markedly different $K_{\mathrm{m}}$ values (Table 4). Significantly less efficient inhibition efficacy of 9 and cemtirestat (4) was recorded for the additional two substrates studied HNE and GS-HNE. Interestingly, compound 9 inhibits AR-mediated reduction of methylglyoxal and HNE more efficiently (3.7 and 3.0 times, respectively) than cemtirestat (4). On one side, this activity may hamper detoxification of these toxic products of carbohydrate metabolism and lipid peroxidation. On the other hand, more efficient inhibition of AR-mediated reduction of the GS-HNE adduct by 9 may attenuate the proinflammatory potential of this metabolic intermediate more efficiently (4 times) than cemtirestat (4). It is well documented that the reduced GS-HNE conjugate takes part in the inflammation signaling. ${ }^{36}$
Clinical trials in diabetic patients ${ }^{37-40}$ revealed the presence of an activated form of human AKR1B1 with a diminished sensitivity to inhibitors. The only catalytically relevant structural variance observed in the activated isozyme was the conversion of residue Cys298 to serine or alanine. Therefore, we have taken the activated form of AR (PDB: 6F8O $)^{41}$ to perform docking and optimization of the resulting inhibitorenzyme complex for compound 9 and cemtirestat (4). As shown in Figure S53 (Supporting Information), both compounds behaved in a similar way, where the original position of the carboxymethyl group was more or less retained, but the tricyclic skeleton was turned in $180^{\circ}$ because of the steric hindrance of $\mathrm{O} \gamma$-Ser298. As a result, the hydrogen bond between the ligands and Leu300, favorable in the native enzyme, could not be created in the activated form of AKR1B1. Accordingly, the calculated values of score function decreased from 8.52 to $7.39 \mathrm{~kJ} / \mathrm{mol}$ for cemtirestat (4) and from 8.81 to $7.51 \mathrm{~kJ} / \mathrm{mol}$ for compound 9. The corresponding dissociation constants increased markedly, from 569 to 3800 $\mathrm{nM}$ for cemtirestat (4) and from 347 to $3140 \mathrm{nM}$ for compound 9. These preliminary findings need further experimental corroboration.

The in vitro experiments performed at the level of isolated enzymes were complemented with the ex vivo studies performed at the organ level of isolated rat eye lenses. The significantly elevated sorbitol accumulation in the lenses incubated with glucose reflects increased flux of glucose through the polyol pathway. Significant inhibition of the lens sorbitol by 9 was recorded at a concentration as low as $10 \mu \mathrm{M}$ (Figure 6). At $50 \mu \mathrm{M}$, the inhibition accounted for approximately $75 \%$ for 9 , while about 60 and $25 \%$ inhibition was recorded for equimolar concentrations of cemtirestat $(4)^{1}$ and epalrestat, ${ }^{39}$ respectively. Apparently, the final response observed at an organ level is the consequence of interplay of physicochemical properties (lipophilicity and ionizability) determining bioavailability and inhibition efficacy of an inhibitor.

Inhibition of sorbitol dehydrogenase, the second enzyme of the polyol pathway, concurrently with inhibition of AR, would, at least partially, eliminate the sorbitol-decreasing effect of AR inhibition. Obviously this is not the case because no significant inhibition of sorbitol dehydrogenase activity by 9 at a concentration as high as $100 \mu \mathrm{M}$ was recorded $[I(\%)=0.9$ $\pm 0.6, n=3]$. Similar finding was reported for cemtirestat $(4){ }^{2}$

In our previous study, cemtirestat (4) was reported as a free radical scavenger and chain breaking antioxidant. ${ }^{18}$ Here we compared antiradical activity of compound 9 with that of cemtirestat (4) in a DPPH test. As shown in Figure 7, cemtirestat (4) started a considerable absorbance diminution, corresponding to the transfer of the most labile $\mathrm{H}$ atom, which was followed by a rather sluggish absorbance drop reflecting the radical scavenging activity of the antioxidant degradation products. Differently, compound 9 affected DPPH absorbance only marginally, pointing to its decreased radical scavenging activity compared to sulfur-containing cemtirestat (4). DPPH, a feeble hydrogen atom abstractor, is regarded as a good kinetic analogue for peroxyl $\mathrm{ROO}^{\bullet}$ radicals. ${ }^{42}$ Yet on the basis of the kinetics of DPPH decolorization, the free radical scavenging efficacy of 9 still exceeded that of compound 14 and also the equimolar melatonin used as a standard antioxidant (Table 5).

Molecular obesity indices, taking into account efficacy, size, and lipophilicity, were calculated for the novel OTIs 9, 10, 12, 
and 14 (Table 6). Calculated values of the ligand efficiency (LE) and the binding efficiency index (BEI) were found in the range of optimal values $\left(>0.3\right.$ and $>14.7$, respectively). ${ }^{19-22}$ For compounds 9, 10, and 14, high inhibition efficacy characterized by $\mathrm{pIC}_{50}$ values close to 7 in combination with low values of $\log P$ resulted in the lipophilic LE values (LLE = $\left.\mathrm{pIC}_{50}-\log P\right)$ above the lower limit for successful lead 3.8. ${ }^{21}$ The LLE figures above 5 point to the preference of specific binding to $\mathrm{AR} .{ }^{43}$ On the other hand, less-specific interactions are expected for compound 12. As shown in Table 6, the ligand-efficiency-dependent lipophilicity (LELP) values are in the recommended range $<7.5^{20}$ with the exception of compound 12. This finding suggests lower drug-likeness of 12 in comparison with the remaining compounds. Moreover, the replacement of sulfur in $\mathbf{4}$ with oxygen in $\mathbf{9}$ resulted in decrease of the LELP index from 3.4 to 3.0. The drop in the LELP index supports the preferred role of specific component in binding of 9 to the enzyme. As a result markedly elevated selectivity relative to structurally related AKR1A1 was recorded for 9 in comparison to 4 (see Table 2). All of the compounds shown in Table 6 meet the threshold criteria of the topological polar surface area (TPSA) $\left(60-140 \AA^{2}\right)$ for good oral absorbtion. ${ }^{22,44}$

\section{CONCLUSIONS}

Structure modification of the original carboxymethylated thioxotriazinoindole cemtirestat (4) by isosteric replacement of sulfur with oxygen in combination with variable $\mathrm{N}-2$ simple substituents provided novel derivatives $\mathbf{9}$ and $\mathbf{1 4}$ with increased AR inhibition efficacy and markedly increased selectivity yet with decreased free radical scavenging ability. Molecular obesity values indicate excellent drug-likeness of the novel OTI derivatives with favorable oral bioavailability predicted. To continue this research, Biomagi Inc. has already designed additional OTI derivatives, presently under preparation, with expected better ALR2 affinity, solubility, and also improved antioxidant action.

\section{EXPERIMENTAL SECTION}

Computational Methods. The initial structures of compounds were calculated by the equilibrium conformer search procedure (MMFF94) in the program SPARTAN'08 (Wavefunction, Inc., Irvine, CA, 2009). The geometries of individual tautomers for compound 9 (tautomers analogical to those calculated for compound cemtirestat (4) in the paper of Stefek et al. ${ }^{1}$ ) were obtained by full optimization in the DFT B3LYP 6-31G* method in vacuum, in water, and in DMSO. The energies of solvated tautomers in water and in DMSO were calculated by the SM8 method of Cramer and Truhlar. ${ }^{45}$

The structure of human recombinant enzyme AKR1B1 in the complex with $\mathrm{NADP}^{+}$and cemtirestat (4) (PDB: 4QX4) ${ }^{1}$ was used for docking. The optimal conformers of the inhibitors were docked into the enzyme-cofactor complex by the program Yasara ${ }^{46}$ using the AMBER14 force field ${ }^{47}$ and utilizing the flexible ligands option. The first five clusters (if existing) as ordered by AutoDock binding energy were then optimized in water. The simulation cell overlapping the complex by $8 \AA$ was filled by water molecules (final density $0.997 \mathrm{~g}$ / $\mathrm{mL}$ ) and $\mathrm{Na}^{+}$and $\mathrm{Cl}^{-}$ions in the amount of $0.9 \%$ of the overall mass of the water environment. The ratio of the ions was chosen to neutralize the final charge of the complex. Recalculation of $\mathrm{p} K_{\mathrm{a}}$ values of amino acids was performed and $\mathrm{pH} 6.2$ was maintained. ${ }^{48} \mathrm{~A}$ standard optimization protocol, which consists of the steepest gradient optimization, molecular dynamics and simulated annealing, was used. The rational geometry with the highest binding energy (according to Yasara convention) was chosen for analysis of the key interactions. To validate the protocol, a cross-docking procedure was performed and confirmed a high value of accuracy of $90.0 \% .{ }^{17}$ In order to compare the complexes with compound 9 and with cemtirestat (4), the original PDB: 4QX4 structure was relaxed with the same optimization protocol.

Chemical Syntheses. Starting chemicals for syntheses were purchased from Sigma-Aldrich (St. Louis, MO, USA), Fluorochem (Hadfield, UK), AlfaAesar (part of Thermo Fisher Scientific, Heysham, UK), or Acros (part of Thermo Fisher Scientific, Geel, Belgium) vendors. Other chemicals were purchased from local commercial sources and were of analytical grade quality. Melting points were measured by a Digital Melting Point Apparatus Barnstead Electrothermal IA9200 and are uncorrected. ${ }^{1} \mathrm{H}$ - and ${ }^{13} \mathrm{C}$ NMR spectra were recorded on Varian Gemini $(300 / 600$ and 75/150 MHz, resp.); chemical shifts are given in parts per million (ppm), and tetramethylsilane was used as an internal standard and DMSO- $d_{6}$ as the solvent, unless otherwise specified. Infrared (IR) spectra were acquired on Fourier transform infrared spectroscopy (FT-IR)attenuated total reflectance REACT IR 1000 (ASI Applied Systems) with a diamond probe and MTS detector. Mass spectra were performed on liquid chromatography-mass spectrometry (LC-MS; Agilent Technologies 1200 Series equipped with Mass spectrometer Agilent Technologies 6100 Quadrupole LC-MS). The course of the reactions was followed by thin-layer chromatography (TLC) analysis (Merck Silica gel $60 \mathrm{~F} 254)$. A UV lamp (254 nm) and iodine vapors were used for the visualization of TLC spots. All tested compounds 4, 9, 10, 12, and 14 possess purity over 95\%. Their purity was determined by the melting point and combustion analysis (elemental analysis found values for carbon, hydrogen, and nitrogen within $0.4 \%$ of the calculated values for the proposed formula).

Ethyl 2-(2,3-Dioxoindolin-1-yl)acetate (2). A mixture of $2.00 \mathrm{~g}$ ( $13.6 \mathrm{mmol}, 1.00 \mathrm{~mol}$ equiv) isatine 1 and $630 \mathrm{mg}(15.0 \mathrm{mmol}, 1.10$ mol equiv) of $\mathrm{CaH}_{2}$ in $15 \mathrm{~mL}$ of DMF (abs) was stirred at $100{ }^{\circ} \mathrm{C}$ for $1 \mathrm{~h}$ under $\mathrm{Ar}$ and then cooled to $40{ }^{\circ} \mathrm{C}$. At this temperature $4.37 \mathrm{~mL}$ ( $40.8 \mathrm{mmol}, 3.00 \mathrm{~mol}$ equiv) of ethyl chloroacetate was added into the reaction mixture within $10 \mathrm{~min}$. The resulting mixture was heated to $100{ }^{\circ} \mathrm{C}$ for $5 \mathrm{~h}$ and then allowed to cool to rt. The reaction was poured into a vigorously stirred aqueous $0.5 \mathrm{M} \mathrm{HCl}$ solution (50 $\mathrm{mL}$ ), which resulted in a red precipitate. The obtained solid material was filtered off and washed with $\mathrm{H}_{2} \mathrm{O}$. The crude product was further purified by trituration in a mixture of hexane/ethyl acetate to afford $1.93 \mathrm{~g}$ (8.28 mmol, 61\%) of ethyl 2-(2,3-dioxoindolin-1-yl)acetate (2) as a red solid material.

Novelty: The synthesis of compound $\mathbf{2}$ was previously described in the literature with a quantitative yield and characterized by its $\mathrm{mp}$, ${ }^{1} \mathrm{H}-,{ }^{13} \mathrm{C}$ NMR, IR, MS, and HRMS spectrum. ${ }^{8}$

$\mathrm{mp} 125.8-127.5{ }^{\circ} \mathrm{C}\left[\mathrm{DMF} / \mathrm{H}_{2} \mathrm{O}\right]$ (lit. $132-133{ }^{\circ} \mathrm{C}$ ). ${ }^{1} \mathrm{H}$ NMR $\left(300 \mathrm{MHz}, \mathrm{CDCl}_{3}\right): \delta 7.58(\mathrm{dd}, 1 \mathrm{H}, J(4,5)=7.6 \mathrm{~Hz}, J(4,6)=1.3 \mathrm{~Hz}$, $\mathrm{H}-\mathrm{C}(4)), 7.52($ ddd, $1 \mathrm{H}, J(5,6)=9.1 \mathrm{~Hz}, J(6,7)=7.8 \mathrm{~Hz}, J(4,6)=$ $1.3 \mathrm{~Hz}, \mathrm{H}-\mathrm{C}(6)$ ), 7.09 (ddd, $1 \mathrm{H}, J(5,6)=9.1 \mathrm{~Hz}, J(4,5)=7.6 \mathrm{~Hz}$, $J(5,7)=1.3 \mathrm{~Hz}, \mathrm{H}-\mathrm{C}(5)), 6.72(\mathrm{dd}, 1 \mathrm{H}, J(6,7)=7.8 \mathrm{~Hz}, J(5,7)=1.3$ $\mathrm{Hz}, \mathrm{H}-\mathrm{C}(7)), 4.42$ (s, $\left.2 \mathrm{H}, \mathrm{NC} \underline{\mathrm{H}}_{2} \mathrm{COOEt}\right), 4.18\left(\mathrm{q}, 2 \mathrm{H}, \mathrm{J}\left(\mathrm{CH}_{2}, \mathrm{CH}_{3}\right)\right.$ $\left.=7.2 \mathrm{~Hz},-\mathrm{OCH}_{2} \mathrm{CH}_{3}\right), 1.22\left(\mathrm{t}, 3 \mathrm{H}, J\left(\mathrm{CH}_{2}, \mathrm{CH}_{3}\right)=7.2 \mathrm{~Hz}\right.$, $\left.-\mathrm{OCH}_{2} \mathrm{CH}_{3}\right)$.

2-(1-(2-Ethoxy-2-oxoethyl)-2-oxoindolin-3-ylidene)hydrazinecarbimidothioic Acid (3). Ethyl 2-(2,3-dioxoindolin-1yl)acetate (2) $500 \mathrm{mg}(2.15 \mathrm{mmol}, 1.00 \mathrm{~mol}$ equiv) and $235 \mathrm{mg}$ ( $2.58 \mathrm{mmol}, 1.20 \mathrm{~mol}$ equiv) of thiosemicarbazide were dissolved in $10 \mathrm{~mL}$ of DMF (abs) and stirred at $100{ }^{\circ} \mathrm{C}$ for $1 \mathrm{~h}$. Then the reaction mixture was cooled to $\mathrm{rt}$ and $20 \mathrm{~mL}$ of water added. The separated aqueous solution was extracted with EA $(5 \times 10 \mathrm{~mL})$ and the combined organic layer washed with brine $(3 \times 10 \mathrm{~mL})$, dried over $\mathrm{Na}_{2} \mathrm{SO}_{4}$, filtered, and concentrated under reduced pressure. The crude product was purified by trituration in a mixture of hexane/ethyl acetate to yield $539 \mathrm{mg}(1.76 \mathrm{mmol}, 82 \%)$ of 2-(1-(2-ethoxy-2oxoethyl)-2-oxoindolin-3-ylidene)hydrazinecarbimidothioic acid (3) as a red-orange solid material. Novelty: 2-(1-(2-ethoxy-2-oxoethyl)-2oxoindolin-3-ylidene)hydrazinecarbimidothioic acid (3) was not yet described in the literature. mp 209.3-214.0 ${ }^{\circ} \mathrm{C}$ [EA]. ${ }^{1} \mathrm{H}$ NMR (300 $\mathrm{MHz}, \mathrm{DMSO}-\mathrm{d} 6): \delta 12.25,9.14$ and $8.79(3 \times \mathrm{br} \mathrm{s}, 3 \times 1 \mathrm{H},-\mathrm{NH}-$, $=\mathrm{NH}$ and $-\mathrm{SH}), 7.74(\mathrm{dd}, 1 \mathrm{H}, J(4,5)=7.6 \mathrm{~Hz}, J(4,6)=1.3 \mathrm{~Hz}, \mathrm{H}-$ 
$\mathrm{C}(4)), 7.43(\mathrm{ddd}, 1 \mathrm{H}, J(5,6)=8.9 \mathrm{~Hz}, J(6,7)=7.8 \mathrm{~Hz}, J(4,6)=1.3$ $\mathrm{Hz}, \mathrm{H}-\mathrm{C}(6)), 7.18$ (ddd, $1 \mathrm{H}, J(5,6)=8.9 \mathrm{~Hz}, J(4,5)=7.6 \mathrm{~Hz}, J(5,7)$ $=1.3 \mathrm{~Hz}, \mathrm{H}-\mathrm{C}(5)), 7.17(\mathrm{dd}, 1 \mathrm{H}, J(6,7)=7.8 \mathrm{~Hz}, J(5,7)=1.3 \mathrm{~Hz}$, $\mathrm{H}-\mathrm{C}(7)), 4.69\left(\mathrm{~s}, 2 \mathrm{H}, \mathrm{NCH}_{2} \mathrm{COOEt}\right), 4.18\left(\mathrm{q}, 2 \mathrm{H}, J\left(\mathrm{CH}_{2}, \mathrm{CH}_{3}\right)=\right.$ $\left.7.1 \mathrm{~Hz},-\mathrm{OCH}_{2} \mathrm{CH}_{3}\right), 1.22\left(\mathrm{t}, 3 \mathrm{H}, \mathrm{J}\left(\mathrm{CH}_{2}, \mathrm{CH}_{3}\right)=7.1 \mathrm{~Hz}\right.$, $\left.-\mathrm{OCH}_{2} \mathrm{CH}_{3}\right) .{ }^{13} \mathrm{C}$ NMR (75 MHz, DMSO-d6): $\delta$ 179.2, 167.9, $161.2,143.0,131.6,130.8,123.7,121.2,119.6,110.6,61.8$ $\left(-\mathrm{OCH}_{2} \mathrm{CH}_{3}\right), 41.4\left(\mathrm{NCH}_{2} \mathrm{COOEt}\right), 14.4\left(-\mathrm{OCH}_{2} \mathrm{CH}_{3}\right)$. FT-IR (solid, $\mathrm{cm}^{-1}$ ): $3411(\mathrm{~m}), 3240(\mathrm{~m}), 3145(\mathrm{~m}), 2985(\mathrm{w}), 2941(\mathrm{w})$, 1736 (s), 1688 (s), 1612 (s), 1471 (s), 1452 (s), 1418 (m), 1375 (s), $1351(\mathrm{~s}), 1295(\mathrm{w}), 1237(\mathrm{~s}), 1154(\mathrm{~s}), 1103(\mathrm{~s}), 1062(\mathrm{~s}), 1011(\mathrm{~s})$, $885(\mathrm{~m}), 868(\mathrm{~m}), 835(\mathrm{~m}), 786(\mathrm{~m}), 738(\mathrm{~m}), 641(\mathrm{~m}), 619(\mathrm{~m})$, $567(\mathrm{w}), 491(\mathrm{~s}), 456(\mathrm{~s})$. MS (ESI $\mathrm{m} / z): 307.0[\mathrm{M}+\mathrm{H}]^{+}$. Anal. Calcd for $\mathrm{C}_{13} \mathrm{H}_{14} \mathrm{~N}_{4} \mathrm{O}_{3} \mathrm{~S}$ (306.34): C, 50.97; H, 4.61; N, 18.29 Found: C, 50.84; H, 4.49; N, 18.05 .

2-(3-Thioxo-2H-[1,2,4]triazino[5,6-b]indol-5(3H)-yl)acetic Acid (4, Cemtirestat, CMTI). Solution of hydrazinecarbimidothioic acid 3 $600 \mathrm{mg}$ ( $1.96 \mathrm{mmol}, 1.00 \mathrm{~mol}$ equiv) was refluxed in $5 \%$ aq solution of $\mathrm{K}_{2} \mathrm{CO}_{3}(50 \mathrm{~mL})$ for 2 days. After cooling to $\mathrm{rt}$ the mixture was treated with $\mathrm{HCl}(1 \mathrm{M}, \mathrm{aq})$ to $\mathrm{pH}=2$. The obtained solid material was filtered off, washed with water, and dried under reduced pressure to yield $398 \mathrm{mg}(1.53 \mathrm{mmol}, 78 \%)$ of acid 4 (CMTI) as an orange solid product. Novelty: synthesis and characterization of 2-(3-thioxo$2 \mathrm{H}$-[1,2,4] triazino[5,6- $b]$ indol-5(3H)-yl)acetic acid (4) has not yet been described in the literature. $\mathrm{mp} 340-370{ }^{\circ} \mathrm{C}\left[\mathrm{H}_{2} \mathrm{O}\right](\mathrm{dec}) .{ }^{1} \mathrm{H}$ NMR (300 MHz, DMSO- $d_{6}$ ): $\delta 14.67$ (br s, $1 \mathrm{H},-\mathrm{NH}-$ or $-\mathrm{SH}$ ), $13.25($ very br, $1 \mathrm{H},-\mathrm{COOH}) 8.06(\mathrm{dd}, 1 \mathrm{H}, J(8,9)=7.6 \mathrm{~Hz}, J(7,9)=$ $1.4 \mathrm{~Hz}, \mathrm{H}-\mathrm{C}(9)), 7.68-7.65(\mathrm{~m}, 2 \mathrm{H}, \mathrm{H}-\mathrm{C}(6)$ and $\mathrm{H}-\mathrm{C}(7)), 7.41$ $($ ddd, $1 \mathrm{H}, J(7,8)=8.2 \mathrm{~Hz}, J(8,9)=7.6 \mathrm{~Hz}, J(6,8)=1.4 \mathrm{~Hz}, \mathrm{H}-$ $\mathrm{C}(8)), 5.00$ (s, $\left.2 \mathrm{H}, \mathrm{NCH}_{2} \mathrm{COOH}\right) .{ }^{13} \mathrm{C}$ NMR $(150 \mathrm{MHz}$, DMSO$\mathrm{d} 6): \delta 179.5(\mathrm{C}=\mathrm{S}), 169.0(-\mathrm{COOH}), 148.5\left(\mathrm{C}_{4 \mathrm{a}}\right), 144.4\left(\mathrm{C}_{5 \mathrm{a}}\right)$, $135.5\left(\mathrm{C}_{1 \mathrm{a}}\right), 132.3\left(\mathrm{C}_{7}\right), 124.1\left(\mathrm{C}_{8}\right), 122.2\left(\mathrm{C}_{9}\right), 117.5\left(\mathrm{C}_{9 \mathrm{a}}\right), 112.3$ $\left(\mathrm{C}_{6}\right), 43.4\left(\mathrm{NCH}_{2} \mathrm{COOH}\right)$. FT-IR (solid, $\left.\mathrm{cm}^{-1}\right)$ : $3500(\mathrm{w}), 3099$ $(\mathrm{w}), 3020(\mathrm{w}), 2978(\mathrm{w}), 2892(\mathrm{w}), 1736(\mathrm{~m}), 1601(\mathrm{~m}), 1575(\mathrm{~s})$, $1466(\mathrm{~m}), 1438(\mathrm{w}), 1370(\mathrm{~m}), 1258(\mathrm{~m}), 1167(\mathrm{~s}), 1147(\mathrm{~s}), 1073$ (w), $1018(\mathrm{~m}), 945(\mathrm{w}), 811(\mathrm{w}), 784(\mathrm{~m}), 754(\mathrm{~m}), 639(\mathrm{w}), 526$ (m). MS (ESI $m / z): 259.0(10 \%)\left[\mathrm{M}-\mathrm{H}^{+}\right]^{-}, 214.9(100 \%)[\mathrm{M}-$ $\left.\mathrm{CO}_{2}-\mathrm{H}^{+}\right]^{-}$. Anal. Calcd for $\mathrm{C}_{11} \mathrm{H}_{8} \mathrm{~N}_{4} \mathrm{O}_{2} \mathrm{~S}$ (260.27): C, 50.76; $\mathrm{H}$, 3.10; N, 21.53. Found: C, 50.92; H, 3.32; N, 21.84.

2-(2-Oxoindolin-3-ylidene)hydrazinecarboxamide (5). To a solution of $3.00 \mathrm{~g}(20.4 \mathrm{mmol}, 1.00 \mathrm{~mol}$ equiv $)$ isatine 1 in $40 \mathrm{~mL}$ of EtOH, $2.73 \mathrm{~g}$ (24.5 mmol, $1.20 \mathrm{~mol}$ equiv) semicarbazide hydrochloride was added and the mixture was refluxed for $30 \mathrm{~min}$. Then, $40 \mathrm{~mL}$ of water was added and the mixture was cooled down and stirred for further $30 \mathrm{~min}$. The resulting yellow precipitate was filtered off, washed with water, and dried under an IR lamp and reduced pressure yielding $4.01 \mathrm{~g}(19.6 \mathrm{mmol}, 96 \%)$ of semicarbazone 5 as a yellow solid product. Novelty: 2-(2-oxoindolin-3-ylidene)hydrazinecarboxamide (5) was described in the literature $(90.5 \%$ yield) together with its mp, ${ }^{1} \mathrm{H}$ NMR, bioactivity, ${ }^{10} \mathrm{UV} /$ vis, $\mathrm{IR}^{11}$ and HRMS spectral analyses. ${ }^{12} \mathrm{mp} 248-270{ }^{\circ} \mathrm{C}$ [EtOH] (dec), (lit. 239 $\left.{ }^{\circ} \mathrm{C}\right) .{ }^{1} \mathrm{H}$ NMR $\left(300 \mathrm{MHz}\right.$, DMSO- $\left.d_{6}\right): \delta 11.73$ and $11.10(2 \times \mathrm{br} \mathrm{s}$, $1 \mathrm{H},-\mathrm{NH}-$ and $\left.-\mathrm{NHCONH}_{2}\right), 7.60(\mathrm{dd}, 1 \mathrm{H}, J(4,5)=7.6 \mathrm{~Hz}, J(4,6)$ $=1.3 \mathrm{~Hz}, \mathrm{H}-\mathrm{C}(4)), 7.32(\mathrm{ddd}, 1 \mathrm{H}, J(5,6)=8.9 \mathrm{~Hz}, J(6,7)=7.8 \mathrm{~Hz}$, $J(4,6)=1.3 \mathrm{~Hz}, \mathrm{H}-\mathrm{C}(6)), 7.13\left(\right.$ br s, $\left.2 \mathrm{H},-\mathrm{NH}_{2}\right), 7.08$ (ddd, $1 \mathrm{H}$, $J(5,6)=8.9 \mathrm{~Hz}, J(4,5)=7.6 \mathrm{~Hz}, J(5,7)=1.3 \mathrm{~Hz}, \mathrm{H}-\mathrm{C}(5)), 6.93(\mathrm{dd}$, $1 \mathrm{H}, J(6,7)=7.8 \mathrm{~Hz}, J(5,7)=1.3 \mathrm{~Hz}, \mathrm{H}-\mathrm{C}(7)) .{ }^{13} \mathrm{C}$ NMR $(150$ MHz, DMSO- $\left.d_{6}\right): \delta 163.2(\mathrm{C} 2), 155.5$ (s, $\left.-\mathrm{NHCONH}_{2}\right), 141.9$, $131.9,130.8,122.7,120.8,120.6,111.3$.

6-(2-Aminophenyl)-1,2,4-triazine-3,5(2H,4H)-dione (6). A solution of $4.00 \mathrm{~g}$ ( $19.6 \mathrm{mmol}, 1.00 \mathrm{~mol}$ equiv) semicarbazone 5 was refluxed in $1 \mathrm{M}$ aq solution of $\mathrm{NaOH}(75 \mathrm{~mL})$ overnight. After cooling, the solution was acidified with concentrated acetic acid to $\mathrm{pH}$ $=5$ and stirred for $30 \mathrm{~min}$. The resulting precipitate was filtered off, washed with water, and dried under an IR lamp and reduced pressure to yield $2.77 \mathrm{~g}$ (13.5 mmol, 69\%) of 6-(2-aminophenyl)-1,2,4-triazine$3,5(2 \mathrm{H}, 4 \mathrm{H})$-dione $(6)$ as a yellow solid product. Novelty: compound 6 was described in the literature together with its $\mathrm{mp}$ and $\mathrm{UV} /$ vis spectra. ${ }^{13} \mathrm{mp} 270-320{ }^{\circ} \mathrm{C}\left[\mathrm{H}_{2} \mathrm{O}\right]$ (dec), yellow solid compound (lit. $\left.350{ }^{\circ} \mathrm{C}\right) .{ }^{1} \mathrm{H}$ NMR $\left(300 \mathrm{MHz}, \mathrm{DMSO}-d_{6}\right): \delta 12.27$ and $11.93(2 \times \mathrm{br}$ s, $1 \mathrm{H},-\mathrm{CON} \underline{\mathrm{HCO}}-$ and $=\mathrm{N}-\mathrm{NHCO}-), 7.23(\mathrm{dd}, 1 \mathrm{H}, J(\mathrm{~A} 5, \mathrm{~A} 6)=$ $\left.7.7 \mathrm{~Hz}, J(\mathrm{~A} 4, \mathrm{~A} 6)=1.4 \mathrm{~Hz}, \mathrm{H}-\mathrm{C}_{\mathrm{A}}(6)\right), 7.07(\mathrm{ddd}, 1 \mathrm{H}, J(\mathrm{~A} 4, \mathrm{~A} 5)=8.3$ $\left.\mathrm{Hz}, J(\mathrm{~A} 3, \mathrm{~A} 4)=7.9 \mathrm{~Hz}, J(\mathrm{~A} 4, \mathrm{~A} 6)=1.4 \mathrm{~Hz}, \mathrm{H}-\mathrm{C}_{\mathrm{A}}(4)\right), 6.68(\mathrm{dd}, 1 \mathrm{H}$, $\left.J(\mathrm{~A} 3, \mathrm{~A} 4)=7.9 \mathrm{~Hz}, J(\mathrm{~A} 3, \mathrm{~A} 5)=1.4 \mathrm{~Hz}, \mathrm{H}-\mathrm{C}_{\mathrm{A}}(3)\right), 6.53(\mathrm{ddd}, 1 \mathrm{H}$, $J(\mathrm{~A} 4, \mathrm{~A} 5)=8.3 \mathrm{~Hz}, J(\mathrm{~A} 5, \mathrm{~A} 6)=7.7 \mathrm{~Hz}, J(\mathrm{~A} 3, \mathrm{~A} 5)=1.4 \mathrm{~Hz}, \mathrm{H}-$ $\left.\mathrm{C}_{\mathrm{A}}(5)\right), 5.35$ (br s, $\left.2 \mathrm{H},-\mathrm{NH}_{2}\right) \cdot{ }^{13} \mathrm{C}$ NMR $\left(150 \mathrm{MHz}, \mathrm{DMSO}-d_{6}\right): \delta$ 157.4, 149.8, 147.6, 143.4; 131.0, 130.2; 116.3, 115.8, 115.4. FT-IR (solid, $\left.\mathrm{cm}^{-1}\right)$ : $3491(\mathrm{w}), 3377(\mathrm{w}, \mathrm{NH}), 3018\left(\mathrm{~m}, \mathrm{NH}_{2}\right), 1699(\mathrm{~s}$, $\mathrm{C}=\mathrm{O}), 1609(\mathrm{~s}, \mathrm{C}=\mathrm{O}), 1582(\mathrm{~m}), 1542(\mathrm{~m}), 1465(\mathrm{~m}), 1311(\mathrm{~m})$, $1246(\mathrm{~m}), 1154(\mathrm{~m}), 1040(\mathrm{w}), 848(\mathrm{~m}), 751(\mathrm{~s}), 639(\mathrm{~m}), 552(\mathrm{~m})$, 431 (s). MS (ESI $m / z): 202.9(100 \%)\left[\mathrm{M}-\mathrm{H}^{+}\right]^{-}$.

$2 H$-[1,2,4]Triazino[5,6-b]indol-3(5H)-one (7). A suspension of $2.77 \mathrm{~g}$ ( $13.5 \mathrm{mmol}, 1.00 \mathrm{~mol}$ equiv) 6 in $50 \mathrm{~mL}$ of conc. acetic acid was refluxed for $3 \mathrm{~h}$. After cooling to $0{ }^{\circ} \mathrm{C} 20 \mathrm{~mL}$, water was added and the resulting suspension was stirred for another $30 \mathrm{~min}$ in an ice bath. The obtained solid was filtered off, washed with water, and dried under an IR lamp and reduced pressure to yield $2.23 \mathrm{~g}$ $(12.0 \mathrm{mmol}, 88 \%)$ of $2 \mathrm{H}$-[1,2,4] triazino[5,6- $b]$ indol-3 $(5 H)$-one $(7)$ as a yellow solid product. Novelty: $2 \mathrm{H}$-[1,2,4] triazino[5,6-b]indol$3(5 \mathrm{H})$-one (7) was described in the literature together with its $\mathrm{mp}$, ${ }^{1} \mathrm{H}$ NMR, IR and MS spectrum. ${ }^{14} \mathrm{mp} 320-360{ }^{\circ} \mathrm{C}[\mathrm{AcOH}](\mathrm{dec})$, (lit. $\left.280{ }^{\circ} \mathrm{C}\right) .{ }^{1} \mathrm{H}$ NMR $\left(300 \mathrm{MHz}, \mathrm{DMSO}-d_{6}\right): \delta 13.01$ and $11.91(2$ $\times$ br s, $1 \mathrm{H},-\mathrm{NHCO}-$ and $\mathrm{ArNH}-), 7.89(\mathrm{dd}, 1 \mathrm{H}, J(8,9)=7.7 \mathrm{~Hz}$, $J(7,9)=1.3 \mathrm{~Hz}, \mathrm{H}-\mathrm{C}(9)), 7.53(\mathrm{ddd}, 1 \mathrm{H}, J(7,8)=8.0 \mathrm{~Hz}, J(6,7)=$ $7.9 \mathrm{~Hz}, J(7,9)=1.3 \mathrm{~Hz}, \mathrm{H}-\mathrm{C}(7)), 7.31(\mathrm{dd}, 1 \mathrm{H}, J(6,7)=7.9 \mathrm{~Hz}$, $J(6,8)=1.3 \mathrm{~Hz}, \mathrm{H}-\mathrm{C}(6)), 7.26(\mathrm{ddd}, 1 \mathrm{H}, J(7,8)=8.0 \mathrm{~Hz}, J(8,9)=$ $7.7 \mathrm{~Hz}, J(6,8)=1.3 \mathrm{~Hz}, \mathrm{H}-\mathrm{C}(8)) .{ }^{13} \mathrm{C}$ NMR $\left(75 \mathrm{MHz}, \mathrm{DMSO}-d_{6}\right)$ : $\delta 155.5,155.2 ; 146.7,133.2 ; 131.1,122.7 ; 121.4,118.5,112.7 . \mathrm{MS}$ $($ ESI $m / z): 184.9(100 \%)[\mathrm{M}-\mathrm{H}]^{-}$. Anal. Calcd for $\mathrm{C}_{9} \mathrm{H}_{6} \mathrm{~N}_{4} \mathrm{O}$ (186.17): C, 58.06; H, 3.25; N, 30.09; Found: C, 58.22; H, 3.43; N, 30.19 .

Ethyl 2-(3-Oxo-2H-[1,2,4]triazino[5,6-b]indol-5(3H)-yl)acetate (8a) and Diethyl 2,2'-(3-OxO-2H-[1,2,4]triazino[5,6-b]indole2,5(3H)-diyl) diacetate (8b). A mixture of $1.40 \mathrm{~g}(7.52 \mathrm{mmol}, 1.00$ mol equiv) 7 and $474 \mathrm{mg}$ ( $11.30 \mathrm{mmol}, 1.50 \mathrm{~mol}$ equiv) of $\mathrm{CaH}_{2}$ in $15 \mathrm{~mL}$ of DMF (abs) was stirred at $60^{\circ} \mathrm{C}$ for 40 min under $\mathrm{Ar}$ and then cooled to rt. Then $1.61 \mathrm{~mL}(15.04 \mathrm{mmol}, 2.00 \mathrm{~mol}$ equiv $)$ of ethyl chloroacetate was added dropwise via a syringe into the reaction mixture within $10 \mathrm{~min}$ and afterward the mixture was heated to $50^{\circ} \mathrm{C}$. The experiment with $1.1 \mathrm{~mol}$ ekv of ethyl chloroacetate was not performing well, and only a low amount of the two products was formed. After $3 \mathrm{~h}$ a TLC analysis confirmed the formation of products $8 a, 8 b$, and starting material 7 in a ratio: $8 a / 8 b / 7=2.0 / 2.5 / 1.0$. Continuation of reaction mixture heating produced mostly the bisalkylating product $\mathbf{8 b}$; therefore, the mixture was cooled to $\mathrm{rt}$ and poured into a vigorously stirred aqueous $0.5 \mathrm{M} \mathrm{HCl}$ solution ( 50 $\mathrm{mL}$ ), which resulted in an orange precipitate. The solution obtained after filtration was extracted with EA $(5 \times 10 \mathrm{~mL})$ and washed with brine and water. A combined organic layer was dried over $\mathrm{Na}_{2} \mathrm{SO}_{4}$, filtered, and concentrated under reduced pressure. A crude product was purified by $\mathrm{FLC}\left(\mathrm{SiO}_{2}, \mathrm{DCM} / \mathrm{MeOH}=14 / 1\right)$ to give $450 \mathrm{mg}$ $(1.65 \mathrm{mmol}, 22 \%)$ of monoester $\mathbf{8 a}$ as a white solid compound and $539 \mathrm{mg}(1.51 \mathrm{mmol}, 20 \%)$ of diester $\mathbf{8 b}$ as an orange crystalline compound.

8a. Novelty: ethyl 2-(3-oxo- $2 H$ - $[1,2,4]$ triazino $[5,6-b]$ indol-5 $(3 H)$ $\mathrm{yl}$ )acetate (8a) was not yet described in the literature. $\mathrm{mp} 248.0-$ $252.0{ }^{\circ} \mathrm{C}[\mathrm{MeOH} / \mathrm{DCM}] .{ }^{1} \mathrm{H}$ NMR $\left(300 \mathrm{MHz}, \mathrm{DMSO}-d_{6}\right): \delta 13.14$ (br s, $1 \mathrm{H},-\mathrm{NH}-), 7.95(\mathrm{dd}, 1 \mathrm{H}, J(8,9)=8.0 \mathrm{~Hz}, J(7,9)=1.0 \mathrm{~Hz}$, $\mathrm{H}-\mathrm{C}(9)), 7.58($ ddd, $1 \mathrm{H}, J(6,7)=8.0 \mathrm{~Hz}, J(7,8)=7.3 \mathrm{~Hz}, J(7,9)=$ $1.0 \mathrm{~Hz}, \mathrm{H}-\mathrm{C}(7)), 7.56(\mathrm{dd}, 1 \mathrm{H}, J(6,7)=8.0 \mathrm{~Hz}, J(6,8)=1.0 \mathrm{~Hz}, \mathrm{H}-$ $\mathrm{C}(6)$ ), 7.34 (ddd, $1 \mathrm{H}, J(8,9)=8.0 \mathrm{~Hz}, J(7,8)=7.3 \mathrm{~Hz}, J(6,8)=1.0$ $\mathrm{Hz}, \mathrm{H}-\mathrm{C}(8)), 5.03\left(\mathrm{~s}, 2 \mathrm{H}, \mathrm{NCH}_{2} \mathrm{COOEt}\right), 4.18\left(\mathrm{q}, 2 \mathrm{H}, \mathrm{J}\left(\mathrm{CH}_{2}, \mathrm{CH}_{3}\right)\right.$ $\left.=7.1 \mathrm{~Hz},-\mathrm{OCH}_{2} \mathrm{CH}_{3}\right), 1.22\left(\mathrm{t}, 3 \mathrm{H}, J\left(\mathrm{CH}_{2}, \mathrm{CH}_{3}\right)=7.1 \mathrm{~Hz}\right.$, $\left.-\mathrm{OCH}_{2} \mathrm{CH}_{3}\right) .{ }^{13} \mathrm{C}$ NMR $\left(150 \mathrm{MHz}, \mathrm{DMSO}-d_{6}\right): \delta 167.9$ $\left(-\mathrm{CH}_{2} \mathrm{COO}-\right), 154.8,154.5,144.2,132.6 ; 131.2,123.6,121.4$, $118.0,111.6 ; 62.0 \quad\left(-\mathrm{OCH}_{2} \mathrm{CH}_{3}\right), 42.3\left(-\mathrm{CH}_{2} \mathrm{COOEt}\right), 14.4$ $\left(-\mathrm{OCH}_{2} \mathrm{CH}_{3}\right)$. FT-IR (solid, $\left.\mathrm{cm}^{-1}\right)$ : 3151 (w), 3088 (w), 2980 (w), 2857 (m), 1733 (s), 1656 (s), 1595 (s), 1497 (s), 1408 (s), 1221 $(\mathrm{s}), 1171(\mathrm{~m}), 1061(\mathrm{~m}), 1012(\mathrm{~m}), 965(\mathrm{w}), 919(\mathrm{w}), 788(\mathrm{~m}), 746$ (m), $659(\mathrm{~m}), 604(\mathrm{~m}), 575(\mathrm{~m}), 486(\mathrm{~s})$. MS (ESI $\mathrm{m} / z): 271.0[\mathrm{M}$ 
$-\mathrm{H}]^{-}$. Anal. Calcd for $\mathrm{C}_{13} \mathrm{H}_{12} \mathrm{~N}_{4} \mathrm{O}_{3}$ (272.26): C, 57.35; H, 4.44; N, 20.58. Found: C, 57.13; H, 4.16; N, 20.85.

8b. Novelty: diethyl $2,2^{\prime}$-(3-oxo- $2 H$ - $[1,2,4]$ triazino $[5,6-b]$ indole$2,5(3 \mathrm{H})$-diyl)diacetate $(\mathbf{8 b})$ has not yet been described in the literature. mp $182.0-184.1{ }^{\circ} \mathrm{C}[\mathrm{MeOH} / \mathrm{DCM}] .{ }^{1} \mathrm{H}$ NMR $(300 \mathrm{MHz}$, $\left.\mathrm{CDCl}_{3}\right): \delta 7.92(\mathrm{dd}, 1 \mathrm{H}, J(8,9)=7.7 \mathrm{~Hz}, J(7,9)=1.3 \mathrm{~Hz}, \mathrm{H}-\mathrm{C}(9))$, $7.53($ ddd, $1 \mathrm{H}, J(7,8)=8.1 \mathrm{~Hz}, J(6,7)=8.0 \mathrm{~Hz}, J(7,9)=1.3 \mathrm{~Hz}, \mathrm{H}-$ $\mathrm{C}(7)$ ), 7.30 (ddd, $1 \mathrm{H}, J(7,8)=8.1 \mathrm{~Hz}, J(8,9)=7.7 \mathrm{~Hz}, J(6,8)=1.3$ $\mathrm{Hz}, \mathrm{H}-\mathrm{C}(8)), 7.12(\mathrm{dd}, 1 \mathrm{H}, J(6,7)=8.0 \mathrm{~Hz}, J(6,8)=1.3 \mathrm{~Hz}, \mathrm{H}-$ $\mathrm{C}(6)), 4.99$ and $4.87\left(2 \times \mathrm{s}, 2 \times 2 \mathrm{H}, 2 \times-\mathrm{CH}_{2} \mathrm{COOEt}\right), 4.25$ and $4.22\left(2 \times \mathrm{q}, 2 \times 2 \mathrm{H}, J\left(\mathrm{CH}_{2}, \mathrm{CH}_{3}\right)=7.3 \mathrm{~Hz}, 2 \times-\mathrm{OCH}_{2} \mathrm{CH}_{3}\right), 1.27$ $\left(\mathrm{t}, 2 \times 3 \mathrm{H}, J\left(\mathrm{CH}_{2}, \mathrm{CH}_{3}\right)=7.3 \mathrm{~Hz}, 2 \times-\mathrm{OCH}_{2} \mathrm{CH}_{3}\right) .{ }^{13} \mathrm{C}$ NMR $(75$ $\left.\mathrm{MHZ}, \mathrm{CDCl}_{3}\right): \delta 167.8,166.8,154.5,154.2,144.0,133.5,131.4$, $123.8,122.1,118.2,110.3,62.4$ and $62.0\left(2 \times-\mathrm{OCH}_{2} \mathrm{CH}_{3}\right), 55.0$ and $42.2\left(2 \times \mathrm{NCH}_{2} \mathrm{COOEt}\right), 2 \times 14.3\left(2 \times-\mathrm{OCH}_{2} \mathrm{CH}_{3}\right)$. FT-IR (solid, $\mathrm{cm}^{-1}$ ): $3020(\mathrm{w}), 2910(\mathrm{w}), 2083(\mathrm{w}), 1736$ (s), 1683 (s), 1637 (s), 1604 (s), 1575 (m), 1498 (m), $1464(\mathrm{~m}), 1421(\mathrm{~m}), 1396$ (s), 1374 (s), $1306(\mathrm{~m}), 1275(\mathrm{~m}), 1194(\mathrm{~s}), 1138(\mathrm{~s}), 1109(\mathrm{~s}), 1058(\mathrm{~m})$, $1021(\mathrm{~m}), 952(\mathrm{~m}), 871(\mathrm{w}), 785(\mathrm{~m}), 748(\mathrm{~s}), 592(\mathrm{~m}), 566(\mathrm{~m})$, $496(\mathrm{w}), 430(\mathrm{~s})$. MS (ESI $\mathrm{m} / z): 359.1(70 \%)[\mathrm{M}+\mathrm{H}]^{+}, 381.1$ $(100 \%)[\mathrm{M}+\mathrm{Na}]^{+}$. Anal. Calcd for $\mathrm{C}_{17} \mathrm{H}_{18} \mathrm{~N}_{4} \mathrm{O}_{5}$ (358.35): C, 56.98; $\mathrm{H}, 5.06$; N, 15.63. Found: C, 57.05; H, 5.13; N, 15.74 .

2-(3-Oxo-2H-[1,2,4]triazino[5,6-b]indol-5(3H)-yl)acetic Acid (9). Experiment 1 . To a solution of $200 \mathrm{mg}(0.74 \mathrm{mmol}, 1.00 \mathrm{~mol}$ equiv) ester $8 \mathrm{a}$ in $20 \mathrm{~mL} \mathrm{MeOH}, 59.0 \mathrm{mg}$ (1.48 mmol, $2.00 \mathrm{~mol}$ equiv) of $\mathrm{NaOH}$ in $5 \mathrm{~mL}$ of water was added and the resulted mixture refluxed for $2 \mathrm{~h}$. After consumption of starting material $\mathbf{8 a}$ (confirmed by TLC analysis) the mixture was cooled down in an ice bath and acidified with $1 \mathrm{M}$ aq $\mathrm{HCl}$ to adjust $\mathrm{pH}=4$. After $10 \mathrm{~min}$ of stirring, formation of precipitate was observed. The mixture was stirred for further 20 $\mathrm{min}$ in an ice bath. Then the precipitate was filtered off and dried under reduced pressure to yield $113 \mathrm{mg}(0.46 \mathrm{mmol}, 63 \%)$ of acetic acid (9) as a white-orange solid product. Experiment 2. CMTI 100 $\mathrm{mg}(0.38 \mathrm{mmol}, 1.00 \mathrm{~mol}$ equiv) was added to a solution of $30.0 \mathrm{mg}$ ( $0.75 \mathrm{mmol}, 2.00 \mathrm{~mol}$ equiv) $\mathrm{NaOH}$ in $5 \mathrm{~mL}$ of water. Another solution consisting of $122 \mathrm{mg}\left(0.77 \mathrm{mmol}, 2.00 \mathrm{~mol}\right.$ equiv) $\mathrm{KMnO}_{4}$ and $84.0 \mathrm{mg}(2.10 \mathrm{mmol}, 5.50 \mathrm{~mol}$ equiv) of $\mathrm{NaOH}$ in $5 \mathrm{~mL}$ of water was added dropwise to the above mixture and the resulting suspension was stirred at $\mathrm{rt}$ for $30 \mathrm{~min}$. Then the solid material was filtered off, and the filtrate was acidified with $1 \mathrm{M}$ aq $\mathrm{HCl}$ to $\mathrm{pH}=1$ and refluxed for $5 \mathrm{~min}$ to perform a clear solution, cooled down, and concentrated to half of its volume by RVO. The additional crude product 9 was filtered off, washed with water, and purified by trituration in a mixture of hexane/ethyl acetate to afford finally 84.0 $\mathrm{mg}(0.34 \mathrm{mmol}, 89 \%)$ of acid 9 as a white-orange compound. Novelty: 2-(3-oxo- $2 H$ - $[1,2,4]$ triazino[ $5,6-b]$ indol-5(3H)-yl)acetic acid (9) has not yet been described in the literature. $\mathrm{mp} 288.1-$ $290.0{ }^{\circ} \mathrm{C}\left[\mathrm{H}_{2} \mathrm{O} / \mathrm{H}^{+}\right] .{ }^{1} \mathrm{H}$ NMR (300 MHz, DMSO- $d_{6}$ ): $\delta 13.39$ (very br s, $1 \mathrm{H},-\mathrm{COOH}), 13.20$ (br s, $1 \mathrm{H},-\mathrm{NH}-), 7.99(\mathrm{dd}, 1 \mathrm{H}, J(8,9)=$ $7.3 \mathrm{~Hz}, J(7,9)=1.0 \mathrm{~Hz}, \mathrm{H}-\mathrm{C}(9)), 7.64(\mathrm{ddd}, 1 \mathrm{H}, J(7,8)=8.0 \mathrm{~Hz}$, $J(6,7)=7.6 \mathrm{~Hz}, J(7,9)=1.0 \mathrm{~Hz}, \mathrm{H}-\mathrm{C}(7)), 7.59(\mathrm{dd}, 1 \mathrm{H}, J(6,7)=7.6$ $\mathrm{Hz}, J(6,8)=1.0 \mathrm{~Hz}, \mathrm{H}-\mathrm{C}(6)), 7.38(\mathrm{ddd}, 1 \mathrm{H}, J(7,8)=8.0 \mathrm{~Hz}, J(8,9)$ $=7.3 \mathrm{~Hz}, J(6,8)=1.0 \mathrm{~Hz}, \mathrm{H}-\mathrm{C}(8)), 4.94\left(\mathrm{~s}, 2 \mathrm{H},-\mathrm{C}_{2} \mathrm{COOH}\right) .{ }^{13} \mathrm{C}$ NMR $(75 \mathrm{MHz}$, DMSO-d 6$): \delta 169.2(-\mathrm{COOH}), \quad 154.9$ (-NHCO-), $154.5\left(\mathrm{C}_{4 \mathrm{a}}\right), 144.4\left(\mathrm{C}_{5 \mathrm{a}}\right), 132.7\left(\mathrm{C}_{1 \mathrm{a}}\right), 131.2\left(\mathrm{C}_{7}\right)$, $123.5\left(\mathrm{C}_{8}\right), 121.3\left(\mathrm{C}_{9}\right), 118.0\left(\mathrm{C}_{9 \mathrm{a}}\right), 111.6\left(\mathrm{C}_{6}\right), 42.5\left(-\mathrm{CH}_{2}-\right)$. MS $(\mathrm{ESI} m / z): 242.9(75 \%)[\mathrm{M}-\mathrm{H}]^{-}, 198.9(100 \%)\left[\mathrm{M}-\mathrm{CO}_{2}-\mathrm{H}^{+}\right]^{-}$. Anal. Calcd for $\mathrm{C}_{11} \mathrm{H}_{8} \mathrm{~N}_{4} \mathrm{O}_{3}$ (244.21): C, 54.10; H, 3.30; N, 22.94; Found: C, 54.42; H, 3.61; N, 22.63.

2,2'-(3-Oxo-2H-[1,2,4]triazino[5,6-b]indole-2,5(3H)-diyl)diacetic Acid (10). To a solution of $200 \mathrm{mg}(0.56 \mathrm{mmol}, 1.00 \mathrm{~mol}$ equiv) diester $\mathbf{8 b}$ in $20 \mathrm{~mL}$ of $\mathrm{MeOH}, 78.0 \mathrm{mg}$ ( $1.95 \mathrm{mmol}, 3.50 \mathrm{~mol}$ equiv) of $\mathrm{NaOH}$ in $5 \mathrm{~mL}$ water was added and the mixture was refluxed for $1.5 \mathrm{~h}$. After consumption of starting material $\mathbf{8 b}$ (confirmed by TLC analysis), the reaction mixture was cooled down in an ice bath and acidified with $1 \mathrm{M}$ aq $\mathrm{HCl}$ to $\mathrm{pH}=4$. After $10 \mathrm{~min}$ of stirring, formation of precipitate was observed and the mixture was stirred for further $20 \mathrm{~min}$. Then the precipitate was filtered off and dried under reduced pressure to yield $106 \mathrm{mg}(0.35 \mathrm{mmol}, 63 \%)$ of diacid 10 as a yellow solid product. Novelty: 2,2'-(3-oxo- $2 H$ - $[1,2,4]$ triazino $[5,6-$
b]indole-2,5(3H)-diyl)diacetic acid (10) has not yet been described in the literature. $\mathrm{mp} 296.0-299.0{ }^{\circ} \mathrm{C}[\mathrm{MeOH}] .{ }^{1} \mathrm{H} \mathrm{NMR}(300 \mathrm{MHz}$, DMSO- $\left.d_{6}\right): \delta 13.29(2 \times$ br s, $2 \times 1 \mathrm{H},-\mathrm{COOH}) 7.94(\mathrm{dd}, 1 \mathrm{H}$, $J(8,9)=7.7 \mathrm{~Hz}, J(7,9)=1.3 \mathrm{~Hz}, \mathrm{H}-\mathrm{C}(9)), 7.60(\mathrm{ddd}, 1 \mathrm{H}, J(7,8)=$ $8.1 \mathrm{~Hz}, J(6,7)=8.0 \mathrm{~Hz}, J(7,9)=1.3 \mathrm{~Hz}, \mathrm{H}-\mathrm{C}(7)), 7.33(\mathrm{ddd}, 1 \mathrm{H}$, $J(7,8)=8.1 \mathrm{~Hz}, J(8,9)=7.7 \mathrm{~Hz}, J(6,8)=1.3 \mathrm{~Hz}, \mathrm{H}-\mathrm{C}(8)), 7.59(\mathrm{dd}$, $1 \mathrm{H}, J(6,7)=8.0 \mathrm{~Hz}, J(6,8)=1.3 \mathrm{~Hz}, \mathrm{H}-\mathrm{C}(6)), 4.92$ and $4.86(2 \mathrm{x} \mathrm{s}$, $\left.2 \times 2 \mathrm{H}, 2 \mathrm{x}-\mathrm{CH}_{2} \mathrm{COOH}\right) .{ }^{13} \mathrm{C}$ NMR $(75 \mathrm{MHZ}$, DMSO-d 6 ) $: \delta 169.7$, $169.1,154.3,153.5,144.5,132.5,131.6,123.8,121.6,117.5,111.5$, 55.2 and $42.6\left(2 \times-\mathrm{CH}_{2} \mathrm{COOH}\right)$. FT-IR (solid, $\left.\mathrm{cm}^{-1}\right): 3010(\mathrm{w})$, $2980(\mathrm{w}), 2606(\mathrm{w}), 2345(\mathrm{w}), 1733(\mathrm{~m}), 1690(\mathrm{~m}), 1602(\mathrm{~s}), 1569$ (s), $1503(\mathrm{~m}), 1470(\mathrm{~m}), 1400(\mathrm{~s}), 1340(\mathrm{~m}), 1275(\mathrm{~m}), 1231(\mathrm{~s})$, $1142(\mathrm{~m}), 1118(\mathrm{~m}), 1069(\mathrm{w}), 1001(\mathrm{~m}), 941(\mathrm{~m}), 895(\mathrm{~m}), 789$ (m), $751(\mathrm{~s}), 701(\mathrm{~m}), 646(\mathrm{~m}), 608(\mathrm{~m}), 549(\mathrm{~m}), 513(\mathrm{~m}), 439(\mathrm{~s})$. MS (ESI $m / z): 323.0(40 \%)\left[\mathrm{M}-2 \mathrm{H}^{+}+\mathrm{Na}^{+}\right]^{-}, 248.9$ (100\%) [for example, $\left.\mathrm{M}-2 \mathrm{CO}_{2}+2 \mathrm{H}_{2} \mathrm{O}+\mathrm{e}^{-}\right]^{-}$. Anal. Calcd for $\mathrm{C}_{13} \mathrm{H}_{10} \mathrm{~N}_{4} \mathrm{O}_{5}$ (302.24): C, 51.66; H, 3.33; N, 18.54. Found: C, 51.85; H, 3.59; N, 18.90 .

Ethyl 2-(2-Benzyl-3-oxo-2H-[1,2,4]triazino[5,6-b]indol-5(3H)-yl)acetate (11). To a solution of $60.0 \mathrm{mg}(0.22 \mathrm{mmol}, 1.00 \mathrm{~mol}$ equiv) ester $8 \mathrm{a}$ in $5 \mathrm{~mL}$ DMF (abs), $19.0 \mathrm{mg}$ ( $0.44 \mathrm{mmol}, 2.00 \mathrm{~mol}$ equiv) of $\mathrm{CaH}_{2}$ was added and the reaction mixture was stirred at $50{ }^{\circ} \mathrm{C}$ under Ar for $30 \mathrm{~min}$. Then the mixture was cooled to rt, $102 \mu \mathrm{L}(0.88 \mathrm{mmol}$, 4.00 mol equiv) of benzyl chloride was added dropwise and the solution was stirred at $80{ }^{\circ} \mathrm{C}$ within $4 \mathrm{~h}$ under Ar. After consumption of ester 8a (confirmed by TLC analysis) the reaction mixture was cooled down, $10 \mathrm{~mL}$ of water was added and stirred for $20 \mathrm{~min}$ in an ice bath which led to the formation of a precipitate. The obtained solid material was filtered off, washed with water, and dried under reduced pressure to yield $20.0 \mathrm{mg}(0.06 \mathrm{mmol})$ of product 11 . The filtrate was extracted with EA $(3 \times 10 \mathrm{~mL})$. A combined organic layer was washed with brine and water, dried by $\mathrm{Na}_{2} \mathrm{SO}_{4}$, filtered, and concentrated under reduced pressure to yield another $44.0 \mathrm{mg}(0.12$ $\mathrm{mmol})$ of product 11 . The overall yield of ester 11 was $64 \mathrm{mg},(0.18$ mmol, $80 \%)$. Novelty: ethyl 2-(2-benzyl-3-oxo- $2 H$-[1,2,4]triazino$[5,6-b]$ indol-5 $(3 H)$-yl)acetate $(11)$ has not yet been described in the literature. $\mathrm{mp} 170.0-172.4{ }^{\circ} \mathrm{C}\left[\mathrm{DMF} / \mathrm{H}_{2} \mathrm{O}\right]$, a yellow solid compound. ${ }^{1} \mathrm{H}$ NMR (300 MHz, DMSO- $\left.d_{6}\right): \delta 7.96(\mathrm{dd}, 1 \mathrm{H}$, $J(8,9)=7.6 \mathrm{~Hz}, J(7,9)=1.4 \mathrm{~Hz}, \mathrm{H}-\mathrm{C}(9)), 7.59(\mathrm{ddd}, 1 \mathrm{H}, J(7,8)=$ $8.2 \mathrm{~Hz}, J(6,7)=7.8 \mathrm{~Hz}, J(7,9)=1.4 \mathrm{~Hz}, \mathrm{H}-\mathrm{C}(7)), 7.59(\mathrm{dd}, 1 \mathrm{H}$, $J(6,7)=7.8 \mathrm{~Hz}, J(6,8)=1.4 \mathrm{~Hz}, \mathrm{H}-\mathrm{C}(6)), 7.41-7.22(\mathrm{~m}, 1 \mathrm{H}, \mathrm{H}-$ $\mathrm{C}(8)$ and $5 \mathrm{H}_{\mathrm{Ar}}$ from $\left.\mathrm{Bn}\right), 5.38\left(\mathrm{~s}, 2 \mathrm{H},-\mathrm{CH}_{2} \mathrm{Ph}\right), 5.04(\mathrm{~s}, 2 \mathrm{H}$, $\left.-\mathrm{C}_{2} \mathrm{COOEt}\right), 4.17\left(\mathrm{q}, 2 \mathrm{H}, J\left(\mathrm{CH}_{2}, \mathrm{CH}_{3}\right)=7.1 \mathrm{~Hz},-\mathrm{OCH}_{2} \mathrm{CH}_{3}\right)$, $1.21\left(\mathrm{t}, 3 \mathrm{H}, \mathrm{J}\left(\mathrm{CH}_{2}, \mathrm{CH}_{3}\right)=7.1 \mathrm{~Hz},-\mathrm{OCH}_{2} \mathrm{CH}_{3}\right) .{ }^{13} \mathrm{C} \mathrm{NMR}(75$ MHZ, DMSO- $\left.d_{6}\right): \delta 167.7$ (-COOEt), 154.1, 153.4, 144.2, 137.2, $132.6,131.5,129.0,128.2,128.1,123.6,121.6,117.6,111.7,61.9$ $\left(-\mathrm{O}^{\mathrm{C}} \mathrm{H}_{2} \mathrm{CH}_{3}\right), \quad 56.6\left(\mathrm{PhCH}_{2}-\right) 42.6\left(\mathrm{NC}_{2} \mathrm{COOEt}\right), 14.4$ $\left(-\mathrm{OCH}_{2} \mathrm{CH}_{3}\right.$ ). FT-IR (solid, $\mathrm{cm}^{-1}$ ): $3010(\mathrm{w}), 2337(\mathrm{w}), 2116$ $(\mathrm{w}), 1735$ (s), $1670(\mathrm{~s}), 1635$ (s), $1602(\mathrm{~s}), 1570(\mathrm{~m}), 1498(\mathrm{~m})$, 1466 (m), $1406(\mathrm{~m}), 1373(\mathrm{~m}), 1209(\mathrm{~s}), 1094(\mathrm{~m}), 1041$ (m), 1016 $(\mathrm{m}), 785(\mathrm{~m}), 748(\mathrm{~s}), 705(\mathrm{~s}), 493(\mathrm{~m})$. MS (ESI $\mathrm{m} / z): 363.1$ (100\%) $\left[\mathrm{M}+\mathrm{H}^{+}\right]^{+}, 385.1(50 \%)[\mathrm{M}+\mathrm{Na}]^{+}$. Anal. Calcd for $\mathrm{C}_{20} \mathrm{H}_{18} \mathrm{~N}_{4} \mathrm{O}_{3}$ (362.38): C, 66.29; H, 5.01; N, 15.46. Found: C, 66.39; H, 5.10; N, 15.64 .

2-(2-Benzyl-3-oxo-2H-[1,2,4]triazino[5,6-b]indol-5(3H)-yl)acetic Acid (12). To a solution of $64.0 \mathrm{mg}(0.18 \mathrm{mmol}, 1.00 \mathrm{~mol}$ equiv) ester 11 in $15 \mathrm{~mL}$ of $\mathrm{MeOH}, 14.0 \mathrm{mg}$ (0.35 mmol, $2.00 \mathrm{~mol}$ equiv) of $\mathrm{NaOH}$ in $5 \mathrm{~mL}$ of water was added, and the mixture was refluxed for $2 \mathrm{~h}$. After consumption of starting material 11 (confirmed by TLC analysis) the reaction mixture was cooled down in an ice bath and acidified with $1.0 \mathrm{M}$ aq $\mathrm{HCl}$ to $\mathrm{pH}=4$. After $10 \mathrm{~min}$ of stirring, formation of precipitate was observed and the mixture was stirred for further $20 \mathrm{~min}$. Then the precipitate was filtered off, washed with ice water, and dried under reduced pressure to yield $25.0 \mathrm{mg}(82.8 \mu \mathrm{mol}$, 47\%) of acid 12 as an orange solid product. Novelty: 2-(2-benzyl-3oxo- $2 \mathrm{H}$ - $[1,2,4]$ triazino $[5,6-b]$ indol-5 $(3 H)$-yl)acetic acid $(12)$ has not yet been described in the literature. mp $269.1-274.5^{\circ} \mathrm{C}[\mathrm{MeOH}] .{ }^{1} \mathrm{H}$ NMR (600 MHz, DMSO- $\left.d_{6}\right): \delta 13.05$ (very br s, $\left.1 \mathrm{H},-\mathrm{COOH}\right), 8.02$ $($ dd, $1 \mathrm{H}, J(8,9)=7.6 \mathrm{~Hz}, J(7,9)=1.4 \mathrm{~Hz}, \mathrm{H}-\mathrm{C}(9)), 7.67($ ddd, $1 \mathrm{H}$, $J(7,8)=8.2 \mathrm{~Hz}, J(6,7)=7.8 \mathrm{~Hz}, J(7,9)=1.4 \mathrm{~Hz}, \mathrm{H}-\mathrm{C}(7)), 7.63(\mathrm{dd}$, 
$1 \mathrm{H}, J(6,7)=7.8 \mathrm{~Hz}, J(6,8)=1.4 \mathrm{~Hz}, \mathrm{H}-\mathrm{C}(6)), 7.44-7.33(\mathrm{~m}, 1 \mathrm{H}$, $\mathrm{H}-\mathrm{C}(8)$ and $5 \mathrm{H}_{\mathrm{Ar}}$ from $\left.\mathrm{Bn}\right), 5.44\left(\mathrm{~s}, 2 \mathrm{H},-\mathrm{CH}_{2} \mathrm{Ph}\right), 4.98(\mathrm{~s}, 2 \mathrm{H}$, $\left.-\mathrm{CH}_{2} \mathrm{COOH}\right) .{ }^{13} \mathrm{C}$ NMR (150 MHZ, DMSO-d $): \delta 169.1$ (- $\mathrm{COOH}), 154.1,153.6,144.2,137.2,132.6,131.5,129.0,128.2$, $128.1,123.6,121.5,117.7,111.7,56.6\left(\mathrm{Ph}_{\underline{C}} \mathrm{H}_{2}-\right), 42.5$ $\left(\mathrm{NCH}_{2} \mathrm{COOEt}\right)$. FT-IR (solid, $\left.\mathrm{cm}^{-1}\right) 3651$ (w), 2961 (w), 2100 $(\mathrm{w}), 1890(\mathrm{w}), 1726(\mathrm{~m}), 1626(\mathrm{~m}), 1601(\mathrm{~s}), 1571(\mathrm{~s}), 1500(\mathrm{~m})$, $1469(\mathrm{~m}), 1408(\mathrm{~s}), 1370(\mathrm{~m}), 1245(\mathrm{~s}), 1225(\mathrm{~s}), 1097(\mathrm{~s}), 1050$ (s), $1014(\mathrm{~s}), 926(\mathrm{w}), 796(\mathrm{~s}), 749(\mathrm{~s}), 696(\mathrm{~m}), 665(\mathrm{~m}), 609(\mathrm{~m})$. MS (ESI $\mathrm{m} / z$ ): $333.2(40 \%)\left[\mathrm{M}-\mathrm{H}^{+}\right]^{-}, 289.1(25 \%)\left[\mathrm{M}-\mathrm{CO}_{2}-\right.$ $\left.\mathrm{H}^{-}\right]^{-}, 249.1$ (100\%) [for example, M-Ph- $\left.\mathrm{CO}_{2}+2 \mathrm{H}_{2} \mathrm{O}+\mathrm{e}^{-}\right]^{-}$. Anal. Calcd for $\mathrm{C}_{18} \mathrm{H}_{14} \mathrm{~N}_{4} \mathrm{O}_{3}$ (334.33): C, 64.66; H, 4.22; N, 16.76. Found: C, 64.50; H, 4.04; N, 16.54 .

Ethyl 2-(2-(Methoxymethyl)-3-oxo-2H-[1,2,4]triazino[5,6-b]indol-5(3H)-yl)acetate (13). To a solution of $100 \mathrm{mg}(0.37 \mathrm{mmol}$, $1.00 \mathrm{~mol}$ equiv) ester $8 \mathrm{a}$ in $20 \mathrm{~mL}$ of acetone (abs), $320 \mu \mathrm{L}(1.84$ mmol, $5.00 \mathrm{~mol}$ equiv) of DIPEA (abs) and $139 \mu \mathrm{L}$ (1.84 mmol, 5.00 mol equiv) of $\mathrm{MOMCl}$ were added dropwise and the resulting mixture was stirred at $50{ }^{\circ} \mathrm{C}$ under Ar. After $5 \mathrm{~h}$ of stirring, TLC analysis confirmed the presence of product 13, traces of an unknown side product, and a small amount of starting material 8a (almost no changes were seen by TLC analysis after $16 \mathrm{~h}$ of heating). Then, the reaction mixture was evaporated by $\mathrm{RVO}$, dissolved in $20 \mathrm{~mL}$ of EA, and extracted with water $(3 \times 15 \mathrm{~mL})$. The crude product was purified by crystallization in a mixture of hexane/ethyl acetate to afford $70.0 \mathrm{mg}(0.22 \mathrm{mmol}, 60 \%)$ of ester 13 as a white-orange crystalline compound. Novelty: ethyl 2-(2-(methoxymethyl)-3-oxo$2 H$ - $[1,2,4]$ triazino[ $5,6-b]$ indol-5 $(3 H)$-yl) acetate $(13)$ has not yet been described in the literature. mp $139.0-143.5{ }^{\circ} \mathrm{C}[\mathrm{EA}] .{ }^{1} \mathrm{H}$ NMR $\left(300 \mathrm{MHz}\right.$, DMSO- $\left.d_{6}\right): \delta 7.98(\mathrm{dd}, 1 \mathrm{H}, J(8,9)=7.6 \mathrm{~Hz}, J(7,9)$ $=1.4 \mathrm{~Hz}, \mathrm{H}-\mathrm{C}(9)), 7.62(\mathrm{ddd}, 1 \mathrm{H}, J(7,8)=8.2 \mathrm{~Hz}, J(6,7)=7.8 \mathrm{~Hz}$, $J(7,9)=1.4 \mathrm{~Hz}, \mathrm{H}-\mathrm{C}(7)), 7.58(\mathrm{dd}, 1 \mathrm{H}, J(6,7)=7.8 \mathrm{~Hz}, J(6,8)=1.4$ $\mathrm{Hz}, \mathrm{H}-\mathrm{C}(6)), 7.36$ (ddd, $1 \mathrm{H}, J(7,8)=8.2 \mathrm{~Hz}, J(8,9)=7.6 \mathrm{~Hz}, J(6,8)$ $=1.4 \mathrm{~Hz}, \mathrm{H}-\mathrm{C}(8)), 5.44\left(\mathrm{~s}, 2 \mathrm{H},-\mathrm{CH}_{2} \mathrm{OCH}_{3}\right), 5.05(\mathrm{~s}, 2 \mathrm{H}$, $\left.-\mathrm{CH}_{2} \mathrm{COOEt}\right), 4.19\left(\mathrm{q}, 2 \mathrm{H}, \mathrm{J}\left(\mathrm{CH}_{2}, \mathrm{CH}_{3}\right)=7.0 \mathrm{~Hz},-\mathrm{OCH}_{2} \mathrm{CH}_{3}\right)$, $3.39\left(\mathrm{~s}, 3 \mathrm{H},-\mathrm{CH}_{2} \mathrm{OC} \underline{H}_{3}\right), 1.23\left(\mathrm{t}, 3 \mathrm{H}, J\left(\mathrm{CH}_{2}, \mathrm{CH}_{3}\right)=7.0 \mathrm{~Hz}\right.$, $\left.-\mathrm{OCH}_{2} \mathrm{CH}_{3}\right) .{ }^{13} \mathrm{C}$ NMR $\left(150 \mathrm{MHZ}, \mathrm{DMSO}-d_{6}\right): \delta 167.7$ (-COOEt), 154.4, 153.7, 144.7, 133.1, 131.9, 123.9, 121.8, 117.7, 111.8, 83.1 ( $\left.-\mathrm{CH}_{2} \mathrm{OCH}_{3}\right), 62.0,57.2,42.5$ ( $\left.-\mathrm{CH}_{2} \mathrm{COOEt}\right), 14.5$ $\left(-\mathrm{OCH}_{2} \mathrm{CH}_{3}\right)$. FT-IR (solid, $\left.\mathrm{cm}^{-1}\right): 3051(\mathrm{w}), 2987(\mathrm{w}), 2932(\mathrm{w})$, 1750 (s), 1670 (s), 1631 (s), 1603 (s), 1570 (s), 1450 (m), 1456 (m), $1425(\mathrm{~m}), 1406(\mathrm{~m}), 1370(\mathrm{~m}), 1329(\mathrm{w}), 1268(\mathrm{w}), 1215(\mathrm{~s})$, $1160(\mathrm{~s}), 1092$ (s), $1066(\mathrm{~s}), 1003$ (s), 975 (m), 915 (m), 909 (m), 788 (s), 607 (s). MS (ESI $m / z): 317.2(75 \%)\left[\mathrm{M}+\mathrm{H}^{+}\right]^{+}, 339.2$ (100\%) $\left[\mathrm{M}+\mathrm{Na}^{+}\right]^{+}$. Anal. Calcd for $\mathrm{C}_{15} \mathrm{H}_{16} \mathrm{~N}_{4} \mathrm{O}_{4}$ (316.31): C, 56.96; $\mathrm{H}, 5.10 ; \mathrm{N}, 17.71$. found: C, 57.12; H, 5.22; N, 17.89 .

2-(2-(Methoxymethyl)-3-oxo-2H-[1,2,4]triazino[5,6-b]indol$5(3 \mathrm{H})$-yl)acetic Acid (14). To a solution of $70.0 \mathrm{mg}(0.22 \mathrm{mmol}, 1.00$ mol equiv) ester 13 in $15 \mathrm{~mL}$ of $\mathrm{MeOH}, 18.0 \mathrm{mg}$ ( $0.45 \mathrm{mmol}, 2.00$ mol equiv) of $\mathrm{NaOH}$ in $5 \mathrm{~mL}$ water was added and the mixture refluxed for $1 \mathrm{~h}$. After consumption of starting material 13 (confirmed by TLC analysis), the reaction was cooled down in an ice bath and acidified with $1 \mathrm{M}$ aq $\mathrm{HCl}$ to $\mathrm{pH}=4$. After $20 \mathrm{~min}$ of stirring, formation of precipitate was observed and the mixture was stirred for further $20 \mathrm{~min}$. Then, the precipitate was filtered off, washed with ice water, and dried under reduced pressure to yield $28.0 \mathrm{mg}(0.10 \mathrm{mmol}$, $44 \%)$ of acid 14 as a white solid product. Novelty: 2-(2(methoxymethyl)-3-oxo- $2 \mathrm{H}$-[1,2,4] triazino[5,6-b]indol-5(3H)-yl)acetic acid (14) has not yet been described in the literature. mp 225$270{ }^{\circ} \mathrm{C}[\mathrm{MeOH}](\mathrm{dec}) .{ }^{1} \mathrm{H}$ NMR (300 MHz, DMSO- $\left.d_{6}\right): \delta 13.28$ (very br s, $1 \mathrm{H},-\mathrm{COOH}), 7.97(\mathrm{dd}, 1 \mathrm{H}, J(8,9)=7.6 \mathrm{~Hz}, J(7,9)=1.4$ $\mathrm{Hz}, \mathrm{H}-\mathrm{C}(9)), 7.62(\mathrm{ddd}, 1 \mathrm{H}, J(7,8)=8.2 \mathrm{~Hz}, J(6,7)=7.8 \mathrm{~Hz}, J(7,9)$ $=1.4 \mathrm{~Hz}, \mathrm{H}-\mathrm{C}(7)), 7.35(\mathrm{ddd}, 1 \mathrm{H}, J(7,8)=8.2 \mathrm{~Hz}, J(8,9)=7.6 \mathrm{~Hz}$, $J(6,8)=1.4 \mathrm{~Hz}, \mathrm{H}-\mathrm{C}(8)), 7.58(\mathrm{dd}, 1 \mathrm{H}, J(6,7)=7.8 \mathrm{~Hz}, J(6,8)=1.4$ $\mathrm{Hz}, \mathrm{H}-\mathrm{C}(6)), 5.44\left(\mathrm{~s}, 2 \mathrm{H},-\mathrm{CH}_{2} \mathrm{OCH}_{3}\right), 4.93(\mathrm{~s}, 2 \mathrm{H}$, $-\underline{\mathrm{C}}_{2} \mathrm{COOEt}$ ), 3.39 (s, $\left.3 \mathrm{H},-\mathrm{CH}_{2} \mathrm{OC} \underline{\mathrm{H}}_{3}\right) .{ }^{13} \mathrm{C} \mathrm{NMR}(75 \mathrm{MHz}$, DMSO- $\left.d_{6}\right): \delta 169.1(-\mathrm{COOH}), 154.4\left(\mathrm{C}_{4 \mathrm{a}}\right), 153.8\left(\mathrm{C}_{3}\right), 144.8$ $\left(\mathrm{C}_{5 \mathrm{a}}\right), 133.1\left(\mathrm{C}_{1 \mathrm{a}}\right), 131.9\left(\mathrm{C}_{7}\right), 123.8\left(\mathrm{C}_{8}\right), 121.8\left(\mathrm{C}_{9}\right), 117.7\left(\mathrm{C}_{9 \mathrm{a}}\right)$, $111.8\left(\mathrm{C}_{6}\right), 83.1\left(-\mathrm{CH}_{2} \mathrm{OCH}_{3}\right), 57.2\left(-\mathrm{CH}_{2} \mathrm{OCH}_{3}\right), 42.5\left(-\mathrm{CH}_{2}-\right)$. FT-IR (solid, cm ${ }^{-1}$ ): 3245 (m), 2919 (w), 2080 (w), 1741 (m), 1607 (s), $1576(\mathrm{~s}), 1501(\mathrm{~m}), 1465(\mathrm{~m}), 1411(\mathrm{~m}), 1369(\mathrm{w}), 1267(\mathrm{w})$, 1217 (s), 1166 (s), 1088 (s), $1006(\mathrm{~m}), 915(\mathrm{~m}), 892(\mathrm{w}), 788(\mathrm{~m})$, $748(\mathrm{~s}), 671(\mathrm{~m})$. MS (ESI $m / z): 287.2(85 \%)\left[\mathrm{M}-\mathrm{H}^{+}\right]^{-}, 249.0$ [for example, $\left.\mathrm{M}-\mathrm{CO}_{2}-\mathrm{OMe}+\mathrm{H}_{2} \mathrm{O}+\mathrm{e}^{-}\right]^{-}(100 \%), 243.1$ (55\%) [for example, $\left.\mathrm{M}-\left(\mathrm{CH}_{2} \mathrm{OCH}_{3}\right)^{+}\right]^{-}$. Anal. Calcd for $\mathrm{C}_{13} \mathrm{H}_{12} \mathrm{~N}_{4} \mathrm{O}_{4}$ (288.26): C, 54.17; H, 4.20; N, 19.44. Found: C, 54.35; H, 4.59; N, 19.84.

Ethyl 2-(2-Acetyl-3-oxo-2,3-dihydro-5H-[1,2,4]triazino[5,6-b]indol-5-yl)acetate (15). To a suspension of $25.0 \mathrm{mg}(0.90 \mathrm{mmol}$, $1.00 \mathrm{~mol}$ equiv) ester $8 \mathrm{a}$ in $5 \mathrm{~mL}$ of DCM (abs), $24 \mu \mathrm{L}$ ( $0.14 \mathrm{mmol}$, $1.60 \mathrm{~mol}$ equiv) of DIPEA (abs), $13 \mu \mathrm{L}(0.18 \mathrm{mmol}, 2.00 \mathrm{~mol}$ equiv) of acetyl chloride, and $11.0 \mathrm{mg}(0.09 \mathrm{mmol}, 1.00 \mathrm{~mol}$ equiv) of DMAP were added stepwise, and the resulting mixture was stirred at $40{ }^{\circ} \mathrm{C}$ under Ar. After $1 \mathrm{~h}$ of stirring, TLC analysis confirmed the presence of product $\mathbf{1 5}$ without any side products. Then the reaction mixture was extracted with water $(3 \times 10 \mathrm{~mL})$, combined organic layer dried over $\mathrm{Na}_{2} \mathrm{SO}_{4}$, filtered, and concentrated under reduced pressure to yield $26.0 \mathrm{mg}(0.80 \mathrm{mmol}, 79 \%)$ of crude product 15 as an orange solid compound. Novelty: ethyl 2-(2-acetyl-3-oxo-2,3-dihydro$5 H$ - $[1,2,4]$ triazino $[5,6-b]$ indol-5-yl)acetate $(15)$ has not yet been described in the literature. ${ }^{1} \mathrm{H}$ NMR $\left(300 \mathrm{MHz}, \mathrm{DMSO}-d_{6}\right): \delta 7.99$ $(\mathrm{dd}, 1 \mathrm{H}, J(8,9)=7.6 \mathrm{~Hz}, J(7,9)=1.2 \mathrm{~Hz}, \mathrm{H}-\mathrm{C}(9)), 7.67(\mathrm{ddd}, 1 \mathrm{H}$, $J(7,8)=8.2 \mathrm{~Hz}, J(6,7)=7.6 \mathrm{~Hz}, J(7,9)=1.2 \mathrm{~Hz}, \mathrm{H}-\mathrm{C}(7)), 7.57(\mathrm{dd}$, $1 \mathrm{H}, J(6,7)=7.6 \mathrm{~Hz}, J(6,8)=1.2 \mathrm{~Hz}, \mathrm{H}-\mathrm{C}(6)), 7.37$ (ddd, $1 \mathrm{H}, J(7,8)$ $=8.2 \mathrm{~Hz}, J(8,9)=7.6 \mathrm{~Hz}, J(6,8)=1.2 \mathrm{~Hz}, \mathrm{H}-\mathrm{C}(8)), 5.03(\mathrm{~s}, 2 \mathrm{H}$, $-\mathrm{CH}_{2} \mathrm{COOEt}$ ), 4.19 (q, $\left.2 \mathrm{H}, J\left(\mathrm{CH}_{2}, \mathrm{CH}_{3}\right)=7.1 \mathrm{~Hz},-\mathrm{OCH}_{2} \mathrm{CH}_{3}\right)$, $2.68\left(\mathrm{~s}, 3 \mathrm{H},-\mathrm{COCH}_{3}\right), 1.23\left(\mathrm{t}, 3 \mathrm{H}, J\left(\mathrm{CH}_{2}, \mathrm{CH}_{3}\right)=7.1 \mathrm{~Hz}\right.$, $\left.-\mathrm{OCH}_{2} \mathrm{CH}_{3}\right)$. Because of instability of compound 15 , its $\mathrm{mp},{ }^{13} \mathrm{C}$ NMR, IR, MS and El Anal were not determined.

Methyl 2-(3-Oxo-2-pivaloyl-2,3-dihydro-5H-[1,2,4]triazino[5,6b]indol-5-yl)acetate (17). To a suspension of $25.0 \mathrm{mg}(0.10 \mathrm{mmol}$, 1.00 mol equiv) ester 16 (prepared from 9 and diazomethane solution in $\mathrm{Et}_{2} \mathrm{O}$ in quantitative yield) in $5 \mathrm{~mL}$ of $\mathrm{DCM}(\mathrm{abs}), 25 \mu \mathrm{L}(0.15$ mmol, $1.50 \mathrm{~mol}$ equiv) of DIPEA (abs), $24 \mu \mathrm{L}(0.20 \mathrm{mmol}, 2.00 \mathrm{~mol}$ equiv) of pivaloyl chloride, and $12.0 \mathrm{mg}(0.10 \mathrm{mmol}, 1.00 \mathrm{~mol}$ equiv $)$ of DMAP were added stepwise and the resulting mixture was stirred at $30{ }^{\circ} \mathrm{C}$ under Ar. After $15 \mathrm{~min}$ of stirring, TLC analysis confirmed the presence of product 17 without any side products. Then the reaction mixture was extracted with water $(3 \times 10 \mathrm{~mL})$, combined organic layer dried by $\mathrm{Na}_{2} \mathrm{SO}_{4}$, filtered, and concentrated under reduced pressure to yield $26.0 \mathrm{mg}(0.80 \mathrm{mmol}, 79 \%)$ of crude product 17 as an orange solid compound. Novelty: methyl 2-(3-oxo-2pivaloyl-2,3-dihydro- $5 \mathrm{H}$-[1,2,4] triazino[5,6-b]indol-5-yl)acetate (17) has not yet been described in the literature. ${ }^{1} \mathrm{H}$ NMR $(300 \mathrm{MHz}$, DMSO- $\left.d_{6}\right): \delta 8.06(\mathrm{dd}, 1 \mathrm{H}, J(8,9)=7.6 \mathrm{~Hz}, J(7,9)=1.4 \mathrm{~Hz}, \mathrm{H}-$ $\mathrm{C}(9)), 7.71(\mathrm{ddd}, 1 \mathrm{H}, J(7,8)=8.2 \mathrm{~Hz}, J(6,7)=7.8 \mathrm{~Hz}, J(7,9)=1.4$ $\mathrm{Hz}, \mathrm{H}-\mathrm{C}(7)), 7.57$ (dd, $1 \mathrm{H}, J(6,7)=7.8 \mathrm{~Hz}, J(6,8)=1.4 \mathrm{~Hz}, \mathrm{H}-$ $\mathrm{C}(6)), 7.44$ (ddd, $1 \mathrm{H}, J(7,8)=8.2 \mathrm{~Hz}, J(8,9)=7.6 \mathrm{~Hz}, J(6,8)=1.4$ $\mathrm{Hz}, \mathrm{H}-\mathrm{C}(8)), 5.15\left(\mathrm{~s}, 2 \mathrm{H},-\mathrm{CH}_{2} \mathrm{COOEt}\right), 3.78(\mathrm{~s}, 3 \mathrm{H}$, $\left.-\mathrm{CH}_{2} \mathrm{COOCH}_{3}\right), 1.42\left(\mathrm{~s}, 9 \mathrm{H},-\mathrm{COC}\left(\mathrm{CH}_{3}\right)_{3}\right)$. Because of chemical instability of compound $17{ }^{13} \mathrm{C}$ NMR, IR, MS and El Anal were not determined.

Detailed descriptions and spectra of all the assayed final products 9 , 10, 12, and 14 together with their intermediates (see Schemes 1-4) are described in the Supporting Information to this paper.

Interference Compounds Assay. The final compounds 4, 9, 10, 12, and $\mathbf{1 4}$ were screened through three in silico tools to filter out potentially false positive compounds with nonspecific interactions (PAINS) and ability to form aggregates, including http://advisor. docking.org, http://www.cbligand.org/PAINS/ and http://zinc15. docking.org/patterns/home. All the compounds passed these filters and no structural alerts were announced.

Animals. Male Wistar rats 8-9 weeks old, weighing 200-230 g, were used as organ donors for ALR2 and ALR1 preparations. Female Wistar rats 9-10 weeks old, weighing $210-250 \mathrm{~g}$, were used as organ donors for ex vivo eye lens incubations. The animals came from the Breeding Facility of the Institute of Experimental Pharmacology and Toxicology, Dobrá Voda (Slovak Republic). The study was approved by the Ethics Committee of the Institute and performed in accordance with the Principles of Laboratory Animal Care (NIH 
Publication 83-25, revised 1985) and the Slovak law regulating animal experiments (Decree 289, Part 139, July 9, 2003).

\section{ASSOCIATED CONTENT}

\section{S Supporting Information}

The Supporting Information is available free of charge at https://pubs.acs.org/doi/10.1021/acs.jmedchem.9b01747.

Structures of the final compounds, graphical abstract of performed reactions, synthetic procedures, mp, NMR spectral data, IR, MS, and elemental analysis, characterizations of all intermediates and prepared products, molecular modeling predictions of compound $\mathbf{9}$ and $\mathbf{4}$ in AKR1A1 (ALR1), molecular modeling predictions of compound 9 in the activated isozyme AKR1B1, interaction diagrams and visualized binding sites of AKR1B1 complexed with cemtirestat (4), tolrestat, zopolrestat, epalrestat, and fidarestat in comparison with those of compound 9, regular experimental procedures including preparation of rat ALR1 and ALR2, ALR1 and ALR2 enzyme assays, rat eye lens cultivation, and sorbitol assay protocols (PDF)

Molecular formula strings of compounds MFS-R3 (CSV)

\section{Accession Codes}

The PDB code for AKR1B1 with bound cemtirestat (4) is 4QX4. The PDB code for activated AKR1B1 with bound citric acid is $6 \mathrm{~F} 8 \mathrm{O}$. The PDB code for AKR1A1 with the bound sulfate ion and [(5Z)-5-\{[3-(carboxymethoxy)-4methoxyphenyl]methylidene $\}$-2,4-dioxo-1,3-thiazolidin-3-yl]acetic acid is 3FX4.

\section{AUTHOR INFORMATION}

\section{Corresponding Author}

*E-mail: Milan.Stefek@savba.sk. Phone: +421 259410668. Fax: +421254775928.

\section{ORCID $\odot$}

Milan Štefek: 0000-0002-2707-8030

\section{Author Contributions}

A.B. proposed the OTI structures, A.B. and M.S. designed the experiments, wrote and critically reviewed the manuscript, M.H. and G.H. performed the chemical syntheses, P.S. collected information about the known ARIs and performed their interaction analysis, G.A. performed a part of spectral assays, L.K. and M.S.P. performed the enzyme assays, and M.M. performed the computer-supported modeling studies.

\section{Notes}

The authors declare no competing financial interest.

\section{ACKNOWLEDGMENTS}

This work was supported by VEGA 2/0005/2018, VEGA 1/ 0670/18, VEGA 1/0127/18, SIVVP project with ITMS code 26230120002, Slovak Research and Development Agency under the contract NO. APVV-15-0455, SAS-Tubitak JRP 2015/7, TUBITAK project no: 215S19, by Biomagi, Ltd. for suggestion of structures of OTI inhibitors, COST Action CA15135 (Mu.Ta.Lig.) and bilateral project APVV SK-FR2015-0014 for networking, and Cotutelle Fellow from Ambassade de France en Slovaquie, Bratislava, for the part of $\mathrm{MH} \mathrm{PhD}$ study.

\section{ABBREVIATIONS}

AKR1B1, aldo-keto reductase family 1, member B1 (human aldose reductase); AKR1A1, aldo-keto reductase family 1 , member A1; AKR1B10, aldo-keto reductase family 1 member B10; AR (ALR2), aldose reductase; ALR1, aldehyde reductase; ARI, aldose reductase inhibitor; BEI, binding efficiency index; CMTI, cemtirestat; DMF, N,N-dimethylformamide; DMSO, dimethyl sulfoxide; DPPH, 2,2-diphenyl-1-picrylhydrazyl; LE, ligand efficiency; LLE, lipophilic ligand efficiency; LELP, ligand efficiency-dependent lipophilicity; O.D., optical density; OTIs, oxo-triazino-indoles; PAINS, pan assay interference compounds; SAR, structure activity relationship; TPSA, topological polar surface area

\section{REFERENCES}

(1) Stefek, M.; Soltesova Prnova, M.; Majekova, M.; Rechlin, C.; Heine, A.; Klebe, G. Identification of Novel Aldose Reductase Inhibitors Based on Carboxymethylated Mercaptotriazinoindole Scaffold. J. Med. Chem. 2015, 58, 2649-2657.

(2) Soltesova Prnova, M.; Ballekova, J.; Gajdosikova, A.; Gajdosik, A.; Stefek, M. A Novel Carboxymethylated Mercaptotriazinoindole Inhibitor of Aldose Reductase Interferes with the Polyol Pathway in Streptozotocin-Induced Diabetic Rats. Physiol. Res. 2015, 64, 587591.

(3) Stefek, M.; Soltesova Prnova, M.; Ballekova, J.; Majekova, M. Cemtirestat, A Novel Aldose Reductase Inhibitor and Antioxidant, in Multitarget Pharmacology of Diabetic Complications. Int. J. Adv. Sci. Eng. Technol. 2016, 4, 41-44.

(4) Toyooka, N.; Kato, A.; Adachi, I. Fused Tricyclic Compound Having Aldose Reductase Inhibitory Activity. U.S. Patent 20,100,145,052 A1, 2010.

(5) Zhan, J.-Y.; Ma, K.; Zheng, Q.-C.; Yang, G.-H.; Zhang, H.-X. Exploring the Interactional Details Between Aldose Reductase (AKR1B1) and 3-Mercapto-5H-1,2,4-Triazino[5,6-B]Indole-5-Acetic Acid through Molecular Dynamics Simulations. J. Biomol. Struct. Dyn. 2019, 37, 1724-1735.

(6) Soltesova Prnova, M.; Svik, K.; Bezek, S.; Kovacikova, L.; Karasu, C.; Stefek, M. 3-Mercapto-5H-1,2,4-Triazino[5,6-b]Indole-5-Acetic Acid (Cemtirestat) Alleviates Symptoms of Peripheral Diabetic Neuropathy in Zucker Diabetic Fatty (ZDF) Rats: A Role of Aldose Reductase. Neurochem. Res. 2019, 44, 1056-1064.

(7) SciFinder Database https://scifinder.cas.org/ (last accessed Oct 18, 2019).

(8) Lötter, A. N. C.; Pathak, R.; Sello, T. S.; Fernandes, M. A.; van Otterlo, W. A. L.; de Koning, C. B. Synthesis of the Dibenzopyrrocoline Alkaloid Skeleton: Indolo[2,1-a]Isoquinolines and Related Analogues. Tetrahedron 2007, 63, 2263-2274.

(9) Hlaváč, J.; Slouka, J.; Hradil, P. 5-Substituted 6-azauracils XVII* Synthesis of 5-( $m$-tolyl)-6-azauracil and Some of its Derivatives. Acta. Univ. Palacki. Olomouc., Fac. Rerum. Nat., Chem. 2000, 39, 33-38.

(10) Seifi, M.; Sheibani, H. Investigation of Reactions Between Binucleophilic Reagents with 2-(2-Oxindolin-3-ylidene)malononitrile Derivatives. Lett. Org. Chem. 2013, 10, 478-481.

(11) Ilič, S. B.; Konstantinovič, S. S.; Savič, D. S.; Veljkovič, V. B.; Gojgič-Cvijovič, G. The Impact of Schiff Bases on Antibiotic Production by Streptomyces Hygroscopicus. Med. Chem. Res. 2010, 19, 690-697.

(12) Hall, M. D.; Salam, N. K.; Hellawell, J. L.; Fales, H. M.; Kensler, C. B.; Ludwig, J. A.; Szakács, G.; Hibbs, D. E.; Gottesman, M. M. Synthesis, Activity, and Pharmacophore Development for Isatin- $\beta$ thiosemicarbazones with Selective Activity toward MultidrugResistant Cells. J. Med. Chem. 2009, 52, 3191-3204.

(13) Ioffe, I. S.; Tomchin, A. B.; Rusakov, E. A. Semicarbazones and Thiosemicarbazones of a Heterocyclic Series. VIII. Transformations of Isatin- $\beta$-Semicarbazones in Alkaline Media. Zh. Obshch. Khim. 1969, 39, 2345-2351. 
(14) Abdel-Sayed, N. I. Novel Routes to Triazino[5,6-b]Indole and Indolo[2,3-b] Quinoxaline Derivatives. Bulg. Chem. Commun. 2009, 4, $362-367$.

(15) Steele, J. W.; Faulds, D.; Goa, K. L. Epalrestat. A Review of its Pharmacology, and Therapeutic Potential in Late-Onset Complications of Diabetes Mellitus. Drugs Aging 1993, 3, 3532-3555.

(16) Whittle, S. R.; Turner, A. J. Biogenic Aldehyde Metabolism in Rat Brain. Differential Sensitivity of Aldehyde Reductase Isoenzymes to Sodium Valproate. Biochim. Biophys. Acta 1981, 657, 94-105.

(17) Majekova, M.; Ballekova, J.; Prnova, M.; Stefek, M. Structure Optimization of Tetrahydropyridoindole-Based Aldose Reductase Inhibitors Improved their Efficacy and Selectivity. Bioorg. Med. Chem. 2017, 25, 6353-6360.

(18) Prnova, M. S.; Ballekova, J.; Majekova, M.; Stefek, M. Antioxidant Action of 3-Mercapto-5H-1,2,4-Triazino[5,6-b] Indole-5Acetic Acid, an Efficient Aldose Reductase Inhibitor, in a 1,1'Diphenyl-2-Picrylhydrazyl Assay and in the Cellular System of Isolated Erythrocytes Exposed to Tert-Butyl Hydroperoxide. Redox Rep. 2015, 20, 282-288.

(19) Hopkins, A. L.; Keserü, G. M.; Leeson, P. D.; Rees, D. C.; Reynolds, C. H. The role of ligand efficiency metrics in drug discovery. Nat. Rev. Drug Discov. 2014, 13, 105-121.

(20) Keserü, G. M.; Makara, G. M. The Influence of Lead Discovery Strategies on the Properties of Drug Candidates. Nat. Rev. Drug Discovery 2009, 8, 203-212.

(21) Perola, E. An Analysis of the Binding Efficiencies of Drugs and their Leads in Successful Drug Discovery Programs. J. Med. Chem. 2010, 53, 2986-2997.

(22) Abad-Zapatero, C. Ligand efficiency indices for effective drug discovery. Expert Opin. Drug Discov. 2007, 2, 469-488.

(23) Alexiou, P.; Pegklidou, K.; Chatzopoulou, M.; Nicolaou, I.; Demopoulos, V. Aldose Reductase Enzyme and its Implication to Major Health Problems of the 21st Century. Curr. Med. Chem. 2009, 16, 734-752.

(24) Ramana, K. V. Aldose Reductase: New Insights for an Old Enzyme. Biomol. Concepts 2011, 2, 103-114.

(25) Ballekova, J.; Soltesova-Prnova, M.; Majekova, M.; Stefek, M. Does Inhibition of Aldose Reductase Contribute to the Antiinflammatory Action of Setipiprant? Physiol. Res. 2017, 66, 687-693.

(26) Costantino, L.; Rastelli, G.; Vianello, P.; Cignarella, G.; Barlocco, D. Diabetes Complications and their Potential Prevention: Aldose Reductase Inhibition and other Approaches. Med. Res. Rev. 1999, 19, 3-23.

(27) Miyamoto, S. Recent Advances in Aldose Reductase Inhibitors: Potential Agents for the Treatment of Diabetic Complications. Expert Opin. Ther. Pat. 2002, 12, 621-631.

(28) Srivastava, S. K.; Ramana, K. V.; Bhatnagar, A. Role of Aldose Reductase and Oxidative Damage in Diabetes and the Consequent Potential for Therapeutic Options. Endocr. Rev. 2005, 26, 380-392.

(29) Ramirez, M. A.; Borja, N. L. Epalrestat: An Aldose Reductase Inhibitor for the Treatment of Diabetic Neuropathy. Pharmacotherapy 2008, 28, 646-655.

(30) Chatzopoulou, M.; Alexiou, P.; Kotsampasakou, E.; Demopoulos, V. J. Novel Aldose Reductase Inhibitors: a Patent Survey (2006-present). Expert Opin. Ther. Pat. 2012, 22, 1303-1323.

(31) Maccari, R.; Ottanà, R. Targeting Aldose Reductase for the Treatment of Diabetes Complications and Inflammatory Diseases: New Insights and Future Directions. J. Med. Chem. 2015, 58, 20472067.

(32) Grewal, A. S.; Bhardwaj, S.; Pandita, D.; Lather, V.; Sekhon, B. $S$. Updates on Aldose Reductase Inhibitors for Management of Diabetic Complications and Non-diabetic Diseases. Mini Rev. Med. Chem. 2016, 16, 120-162.

(33) Misuri, L.; Cappiello, M.; Balestri, F.; Moschini, R.; Barracco, V.; Mura, U.; Del-Corso, A. The Use of Dimethylsulfoxide as a Solvent in Enzyme Inhibition Studies: The Case of Aldose Reductase. J. Enzyme Inhib. Med. Chem. 2017, 32, 1152-1158.

(34) Májeková, M. Ligand-Based Drug Design of Novel Aldose Reductase Inhibitors. Future Med. Chem. 2018, 10, 2493-2496.
(35) Del-Corso, A.; Balestri, F.; Di Bugno, E.; Moschini, R.; Cappiello, M.; Sartini, S.; La-Motta, C.; Da-Settimo, F.; Mura, U. A New Approach to Control the Enigmatic Activity of Aldose Reductase. PLoS One 2013, 8, No. e74076.

(36) Srivastava, S. K.; Yadav, U. C. S.; Reddy, A. B. M.; Saxena, A.; Tammali, R.; Shoeb, M.; Ansari, N. H.; Bhatnagar, A.; Petrash, M. J.; Srivastava, S.; Ramana, K. V. Aldose Reductase Inhibition Suppresses Oxidative Stress-Induced Inflammatory Disorders. Chem. Biol. Interact. 2011, 191, 330-338.

(37) Das, B.; Srivastava, S. K. Activation of Aldose Reductase from Human Tissues. Diabetes 1985, 34, 1145-1151.

(38) Srivastava, S. K.; Ansari, N. H.; Hair, G. A.; Awasthi, S.; Das, B. Activation of Human Erythrocyte, Brain, Aorta, Muscle, and Ocular Tissue Aldose Reductase. Metabolism 1986, 35, 114-118.

(39) Grimshaw, C. E.; Lai, C.-J. Oxidized Aldose Reductase: In Vivo Factor, not in Vitro Artifact. Arch. Biochem. Biophys. 1996, 327, 8997.

(40) Balendiran, G. K.; Sawaya, M. R.; Schwarz, F. P.; Ponniah, G.; Cuckovich, R.; Verma, M.; Cascio, D. The Role of Cys-298 in Aldose Reductase Function. J. Biol. Chem. 2011, 286, 6336-6344.

(41) Castellví, A.; Crespo, I.; Crosas, E.; Cámara-Artigas, A.; Gavira, J. A.; Aranda, M. A. G.; Parés, X.; Farrés, J.; Juanhuix, J. Efficacy of Aldose Reductase Inhibitors is Affected by Oxidative Stress Induced Under X-Ray Irradiation. Sci. Rep. 2019, 9, 3177.

(42) Blois, M. S. Antioxidant Determinations by the Use of a Stable Free Radical. Nature 1958, 181, 1199-1200.

(43) Edwards, M. P.; Price, D. A. Role of Physicochemical Properties and Ligand Lipophilicity Efficiency in Addressing Drug Safety Risks. Annu. Rep. Med. Chem. 2010, 45, 380-391.

(44) Palm, K.; Stenberg, P.; Luthman, K.; Artursson, P. Polar Molecular Surface Properties Predict the Intestinal Absorption of Drugs in Humans. Pharm. Res. 1997, 14, 568-571.

(45) Marenich, A. V.; Olson, R. M.; Kelly, C. P.; Cramer, C. J.; Truhlar, D. G. Self-Consistent Reaction Field Model for Aqueous and Nonaqueous Solutions Based on Accurate Polarized Partial Charges. J. Chem. Theory Comput. 2007, 3, 2011-2033.

(46) Krieger, E.; Vriend, G. YASARA View-Molecular Graphics for All Devices-From Smartphones to Workstations. Bioinformatics 2014, 30, 2981-2982.

(47) Maier, J. A.; Martinez, C.; Kasavajhala, K.; Wickstrom, L.; Hauser, K. E.; Simmerling, C. Ff14SB: Improving the Accuracy of Protein Side Chain and Backbone Parameters from ff99SB. J. Chem. Theory Comput. 2015, 11, 3696-3713.

(48) Krieger, E.; Nielsen, J. E.; Spronk, C. A. E. M.; Vriend, G. Fast Empirical pKa Prediction by Ewald Summation. J. Mol. Graphics Modell. 2006, 25, 481-486. 